\title{
Long-Term Evolution and Monitoring at High Temporal Resolution of a Rapidly Retreating Cliff in a Cold Temperate Climate Affected by Cryogenic Processes, North Shore of the St. Lawrence Gulf, Quebec (Canada)
}

\author{
Pascal Bernatchez ${ }^{1,2, *}$, Geneviève Boucher-Brossard ${ }^{1,2}\left(\mathbb{D}\right.$, Maude Corriveau ${ }^{1,2}$, Charles Caulet ${ }^{1}$ \\ and Robert L. Barnett 1,3
}

Citation: Bernatchez, P.; Boucher-Brossard, G.; Corriveau, M.; Caulet, C.; Barnett, R.L. Long-Term Evolution and Monitoring at High Temporal Resolution of a Rapidly Retreating Cliff in a Cold Temperate Climate Affected by Cryogenic Processes, North Shore of the St. Lawrence Gulf, Quebec (Canada). J. Mar. Sci. Eng. 2021, 9, 1418. https:// doi.org/10.3390/jmse9121418

Academic Editor: Giorgio Anfuso

Received: 18 November 2021 Accepted: 7 December 2021 Published: 12 December 2021

Publisher's Note: MDPI stays neutral with regard to jurisdictional claims in published maps and institutional affiliations.

Copyright: (c) 2021 by the authors. Licensee MDPI, Basel, Switzerland. This article is an open access article distributed under the terms and conditions of the Creative Commons Attribution (CC BY) license (https:/ / creativecommons.org/licenses/by/ $4.0 /)$.
1 Geography Department, Research Chair in Coastal Geoscience, Université du Québec à Rimouski, 300 Allée des Ursulines, Rimouski, QC G5L 3A1, Canada; genevieve.brossard@gmail.com (G.B.-B.); maude_corriveau@uqar.ca (M.C.); charles_caulet@uqar.ca (C.C.); R.Barnett@exeter.ac.uk (R.L.B.)

2 Centre d'Études Nordiques (CEN), Université du Québec à Rimouski, 300 Allée des Ursulines, Rimouski, QC G5L 3A1, Canada

3 College of Life and Environmental Sciences, University of Exeter, Exeter EX4 4RJ, UK

* Correspondence: pascal_bernatchez@uqar.ca; Tel.: +1-418-723-1986 (ext. 1364); Fax: +1-418-724-1849

\begin{abstract}
This article focuses on the quantification of retreat rates, geomorphological processes, and hydroclimatic and environmental drivers responsible for the erosion of an unconsolidated finesediment cliff along the north shore of the Gulf of St. Lawrence (Quebec, Canada). Annual monitoring using field markers over a period of twenty years, coupled with photo interpretation and historical archive analysis, indicates an average annual erosion rate of $2.2 \mathrm{~m}$ per year between 1948 and 2017. An acceleration in retreat occurred during the last 70 years, leading to a maximum between 1997 and 2017 (3.4 m per year) and 2000-2020 (3.3 m per year). Daily observations based on six monitoring cameras installed along the cliff between 2008 and 2012 allowed the identification of mechanisms and geomorphological processes responsible for cliff retreat. Data analysis reveals seasonal activity peaks during winter and spring, which account for $75 \%$ of total erosional events. On an annual basis, cryogenic processes represent $68 \%$ of the erosion events observed and subaerial and hydrogeological processes account for $73 \%$. Small-scale processes, such as gelifraction, solifluction, suffosion, debris collapse, and thermoabrasion, as well as mass movement events, such as slides and mudflows, induced rapid cliff retreat. Lithostratigraphy and cliff height exert an important control on erosion rates and retreat modes, which are described by three main drivers (hydrogeologic, cryogenic, and hydrodynamic processes). Critical conditions promoting high erosion rates include the absence of an ice-foot in winter, the absence of snow cover on the cliff face allowing unrestricted solar radiation, the repetition of winter warm spells, snow melting and sediment thawing, and high rainfall conditions (>30 mm or SPI $>2$ ). The relationships between hydroclimatic forcing and retreat rates are difficult to establish without taking into account the quantification of the geomorphological processes involved. The absence of quantitative data on the relative contribution of geomorphological processes can constitute a major obstacle in modeling the retreat of cliffs with regard to climate change.
\end{abstract}

Keywords: cliff erosion; geomorphological processes; cryogenic processes; hydroclimatic forcing; modes of retreat; thermoabrasion; subaerial processes; freeze-thaw processes; cliff monitoring

\section{Introduction}

The erosion of coastal cliffs is conditioned by hydrodynamic processes [1,2], but also hydrogeologic, gravitational, and cryogenic processes [3-5]. Wave action at the cliff toe can also trigger various types of mass movements, including topples, block failures, and landslides. The intensity of the cliff retreat and the relative contribution of the subaerial and marine processes will depend on the geological and lithostratigraphic characteristics 
(type and hardness of strata, position in the cliff) of the cliff, which will determine the resistance to erosion, but also on the geomorphological characteristics of the cliff (height, profile, slope) thus determining the mode of retreat [6-9]. Beach and shore platform geomorphology in front of the cliff will also influence the stability of the cliff $[10,11]$. In addition, the speed of cliff retreat will also depend on hydrometeorological forcing and environmental conditions [12,13], sometimes exacerbated by anthropogenic interventions on the coast, such as sand excavation [14].

Climate-related factors, such as storminess, wind direction, water levels, and wave forcing are crucial environmental drivers in cliff evolution [15]. In the context of rising sea levels, most numerical or semiempirical models are based on the assumption that hydrodynamic processes drive cliff retreat $[2,15,16]$. However, non-marine hydrodynamic variables such as rainfall and frost action are also important $[3,4,17,18]$. Parameterization of these other variables into models is still at an embryonic stage, since few studies have attempted to quantify the interrelation between climatic variables (temperature, precipitation, freezethaw cycles, drought, etc.) and geomorphological processes related to erosion rates [18,19]. In cold regions, in addition to the classic erosion processes, cryogenic processes, which group together all the processes associated with freezing or thawing, also contribute significantly to cliff retreat. The intensity and frequency of several of these variables are set to change with global warming and accelerated sea-level rise [20]. In cold region shorelines, global warming is already affecting cliff erosion in two main ways. First, it increases the air thawing temperature, which favors the melting of the permafrost, which causes landslides, mudflows, and retrogressive thaw slump [21-23]. Second, the reduction in sea ice cover or the increase of the ice-free period duration leads to an increase in water-cliff-toe contact $[20,24,25]$, which promotes thermoabrasion and basal notches as well as block collapse $[12,26,27]$. Some regions of the Arctic have already been experiencing accelerated coastal erosion in recent decades $[5,23,25,28-30]$. Because of the environmental changes induced by global warming, these hydroclimatic forcings will lead to an acceleration of the retreat of the coast $[20,31]$.

Studies on erosion of cliffs in cold regions have been numerous over the last two decades and have mainly focused on the calculation of historical erosion rates mostly at decadal scales [14,25,32-34]; and less often at annual or seasonal scales [27,35,36]. The quantification of erosion at high temporal resolution rarely exceeds a few years, and in rare cases ten years [30]. Short-term evolution also based on LiDAR data and helicopter, aircraft, or drone photogrammetry allows the quantification of coastline or shoreline retreat and eroded volumes [34,35,37-39]. The studies also focused on the influence of the geomorphology and lithology of the cliffs on the rates and modes of retreat $[40,41]$ and on the different mechanisms and modes of block failures and landslides [12,26,42,43].

In the context of climate change, it is essential to assess the influence of environmental drivers on coastal erosion [13,44]. Research has often focussed on the quantification and influence of freeze-thaw cycles [45,46], the influence of snow patch thickness on the thermal regimes on cliffs [47], the increase in air-thawing-degree days and duration of ice-free periods [27,48], and the impact of waves and storms [44]. Even though erosionpredicting models are seldom used in cold coastal regions [49], empirical modeling has been used to assess cliff retreat due to storm surges [50], and numerical modeling to simulate thermoabrasion and subaerial erosion [12,51]. Studies on the influence of environmental drivers on cryogenic processes have mainly been carried out on permafrost coasts. However, few studies have been carried out in cold temperate regions without permafrost but with seasonal frost, where cryogenic processes can contribute up to $65 \%$ of the total annual retreat in cliffs composed of fine sediments $[36,45]$. Despite the progress made in the knowledge of the hydroclimatic forcing involved in cliff retreat, very few studies have so far attempted to quantify the relative contribution of different erosion processes to cliff retreat, particularly in cold regions [36]. In cold temperate regions, some erosion processes such as thermoabrasion, which are expected to intensify with the reduction of the ice cover, have not been fully addressed, but have the potential to occur when the frost is active 
and in the absence of an ice-foot [52]. This gap in the quantification of geomorphological processes is, however, an obstacle towards accurately quantifying environmental drivers of cliff erosion prior to modeling of the coastal system in the context of climate change.

This study presents an approach employing a continuous monitoring of the coastline on a daily basis with the use of surveillance cameras coupled with a long quantitative annual monitoring (twenty years) and historical archive analysis. This approach was tested on a rapidly retreating cliff along the north shore of the Gulf of St. Lawrence (Quebec, Canada) in order to: (i) identify the precise timing of erosional events, (ii) describe continuous erosional processes in terms of magnitude and environmental interactions and (iii) quantify environmental driver conditions occurring at the time of discrete and continuous erosional events. This approach allows us to investigate the relationship between erosional events, cliff retreat rates, and the local hydroclimatic conditions in a cold temperate climate.

\section{Regional Setting}

The study area is located at Rivière Saint-Jean on the north shore of the Gulf of St. Lawrence (Eastern Quebec, Canada) (Figure 1). Over recent decades, the region has experienced more than $2 \mathrm{~m}$ per year of cliff retreat, representing some of the highest rates measured in Quebec [7,53]. The coast comprises raised Holocene deltaic sediments, deposited by the Saint-Jean River during the last deglaciation [54]. The cliff is composed, at the base, of fine prodeltaic sediments finely stratified horizontally. This gray sediment is mostly composed of clayey silt and silty sand with interbedded fine sand (named hereafter the silt-clay unit). This unit is overlain by medium to coarse sands, sometimes with gravel and pebbles of fluvial and littoral origin (named hereafter the sandy unit). Above this unit there is an indurated coarse sand with gravel (named hereafter the orstein unit) [55], which is overlain by a freshwater peat unit $[54,56]$. Extensive peat bogs are found inland and are particularly well-developed in the paleo-channels of the Saint-Jean River running perpendicular to the coast (Figure 2).

With a height varying from 3 to $13 \mathrm{~m}$, the cliff is south-west-oriented and high tides frequently reach the cliff toe. Fetch from the Gulf of St. Lawrence is from the west-southwest $(230 \mathrm{~km})$ or the south-west $(120 \mathrm{~km})$. Swells have a period of 6 to $8 \mathrm{~s}$ and offshore mean wave height is $2 \mathrm{~m}$, but can reach more than $5 \mathrm{~m}$ during storms [57]. The area is exposed to semidiurnal tides ranging between $1.5 \mathrm{~m}$ (mean tides) and $2.4 \mathrm{~m}$ (spring tides) at the tide gauge of Mingan, located $30 \mathrm{~km}$ east of the study area [58]. The mean relative sea-level trend for the tide gauge closest to the study area indicates a rise of $0.9 \pm 0.8 \mathrm{~mm}$ per year between 1973 and 2011 [59]. 

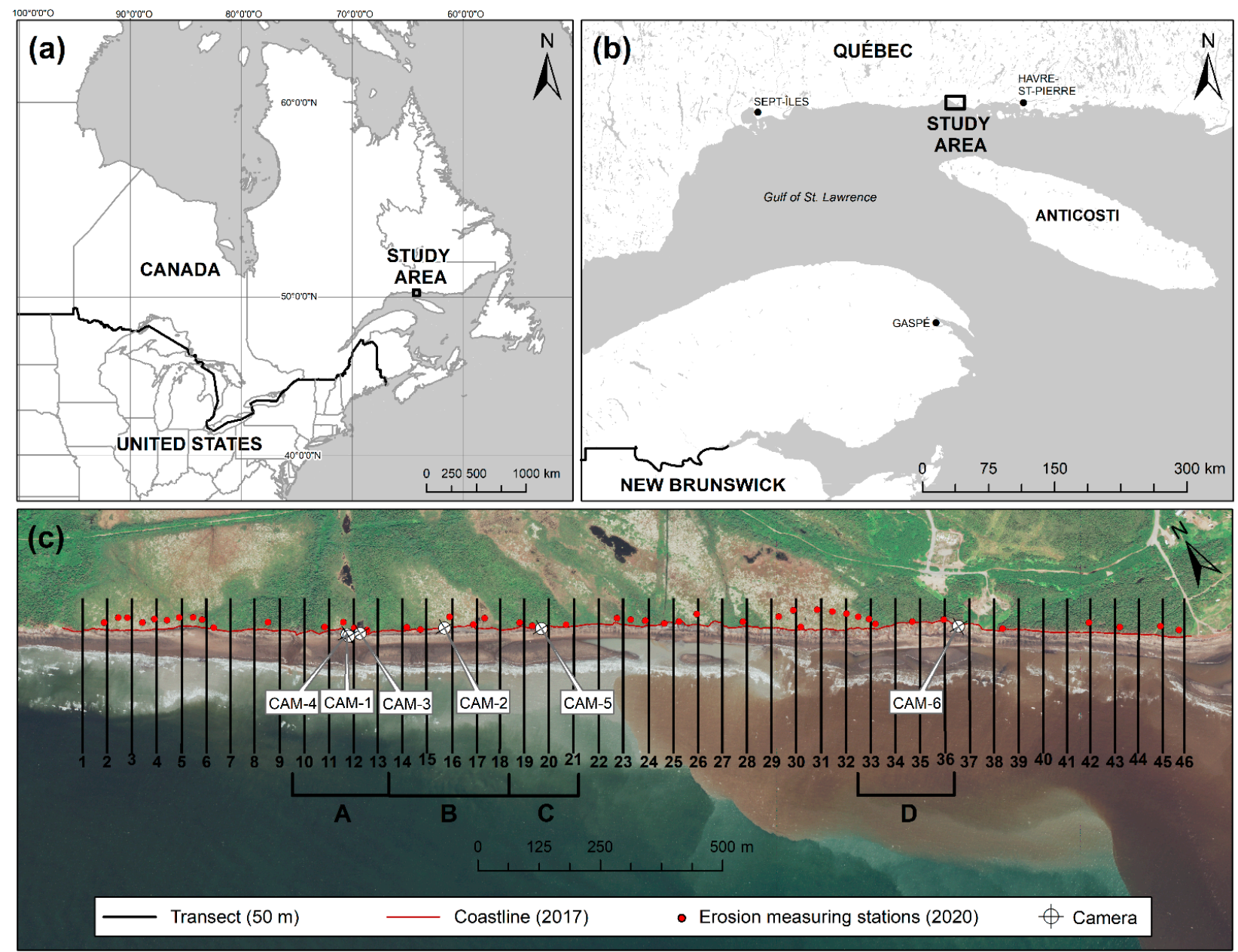

Figure 1. Location of study site. (a) General location; (b) Regional location; (c) Location of the study area, the four zones A-D, transects, erosion stations and cameras.

Prevailing climatic conditions are temperate and humid with relatively short summers and moderately cold winters [60]. Mean annual temperature (normal for 1971-2000) is $1.1^{\circ} \mathrm{C}$ and mean winter temperature over December, January, and February is $-12.1^{\circ} \mathrm{C}$. Precipitation occurs throughout the year (normal 1971-2000 $=1080 \mathrm{~mm}$ ), 23\% of which falls as snow (Station No. 704FEG0 from [61]. Mean wind speed is $15 \mathrm{~km} / \mathrm{h}$, and is higher between December and April (16-17 km/h). Main wind direction is from the west $(27 \%)$ (station number 7043018 from [61]). An ice-foot typically forms on the beach and is present from the end of December until late March or early April. This ice-foot protects the cliff from wave action. 


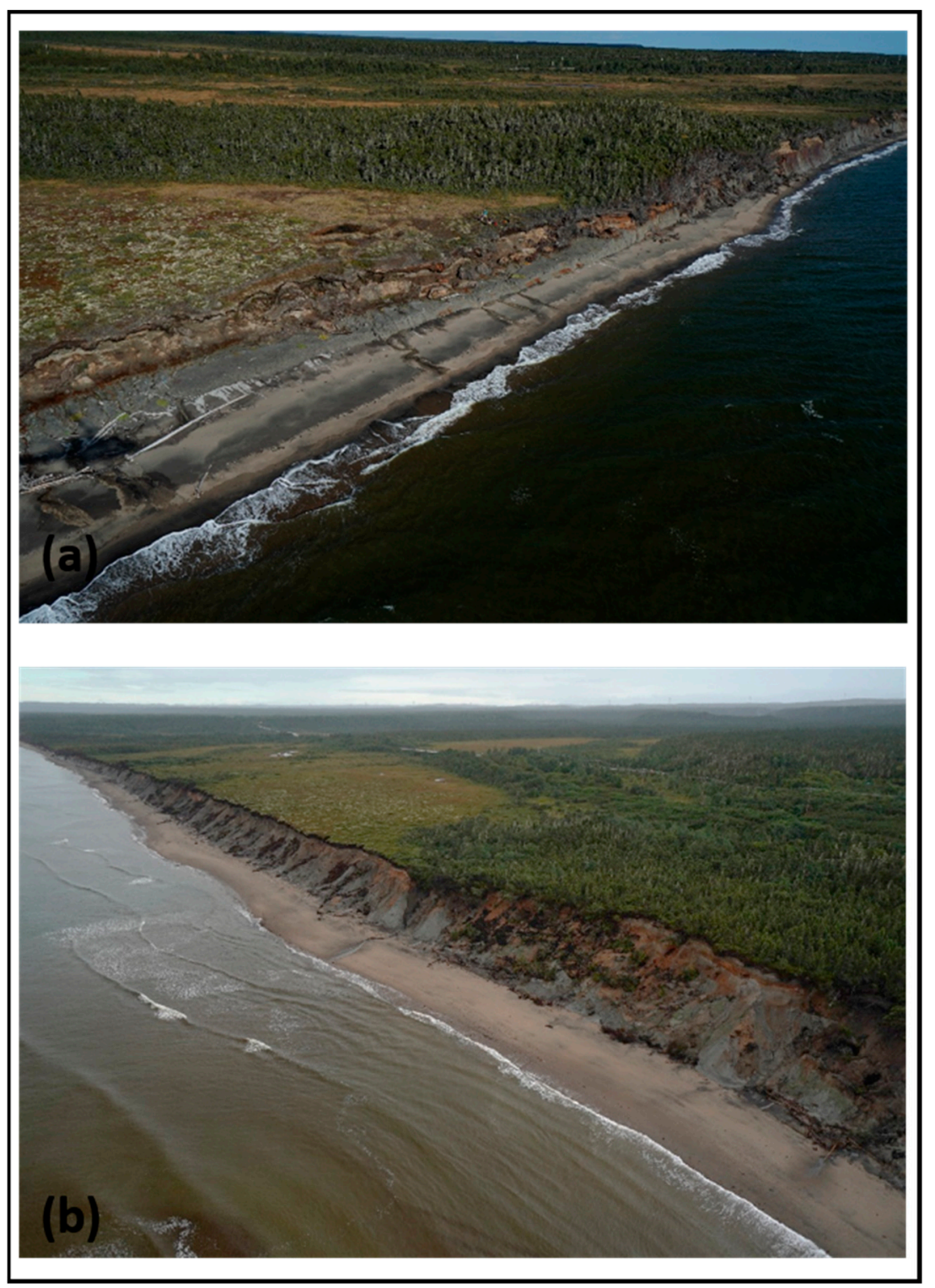

Figure 2. Overview of the study area. (a) Western part, view of zone A and B; (b) eastern part, view of zone D.

\section{Materials and Methods}

\subsection{Historical Cliff Retreat Rates}

The evolution of the cliff has been measured from aerial photography archives from 1948 (1:40,000), 1976 (1:15,000), 1983 (1:40,000), 1989 (1:15,000), 1997 (1:40,000), 2005 (1:20,000) and World View 3 satellite imagery 2017 (31 cm resolution). Photographs were scanned at 600 or $1200 \mathrm{dpi}$ and georeferenced into a geographical information system (GIS, ArcInfo version 9.3.1) using control points from the orthorectified photograph of 2005. The cliff edge was digitized at 1:600 scale and validated using stereoscopy for 1948 to 1997 or available LIDAR for 2005 and 2017. Digital transects were drawn perpendicular to the coastline at regular intervals ( $50 \mathrm{~m}$, Figure 1 ) and used to calculate retreat rates from 1948 to 2017 using the automated procedure of the digital shoreline analysis system (DSAS) extension in ArcGis 9.3.1 [62]. The LiDAR survey of 2005 was used to measure the height of the cliff and to calculate the volume loss associated with the cliff retreat.

Cliff retreat error estimations were calculated as mean annual uncertainties $\left(E_{a}\right)$ using a root sum-of-squares method [63-65] over time $(T)$. Error terms include a georeferencing error $\left(E G_{p s-p s}\right)$, estimated using misfits between ground features, a digitizing error 
(0.001 mm-considered null) and a digitizer-operator error $\left(E D O_{p s}\right)$ calculated as 1.5 pixel size by repeated trials to test reproducibility. Maximal annualized errors $\left(E_{a}\right)$ vary between \pm 0.04 and $\pm 0.39 \mathrm{~m}$.

$$
E_{a}=\frac{\sqrt{E G_{p s 1-p s 2}^{2}+E D O_{p s 1}^{2}+E D O_{p s 2}^{2}}}{T}
$$

\subsection{Annual Cliff Retreat}

A network of 46 coastal erosion measurement stations was set up at the top of the cliff in 2000 (Figure 1). The stations correspond to survey stakes where the distance to the top of the cliff edge was measured annually on the field between 2000 and 2020. An uncertainty range of $\pm 5 \mathrm{~cm}$ has been estimated for each measure.

\subsection{Continuous Monitoring System for Erosion Events Detection}

To identify erosion events and geomorphological processes and the environmental factors involved, four distinguishable zones (Figures 1 and 3) were studied and equipped with six cameras (Reconyx model PC85-3.1 megapixels, USA) from December 2008 to December 2012 (Table 1). Zone A is characterized by a $25 \mathrm{~m}$-wide sand and gravel beach with an average cliff height of $4.4 \mathrm{~m}$ (Table 2). An open peat bog occupies the inland area behind the cliff line along this part of the coast. Zone B is characterized by a progressive thickening of the basal silt-clay unit, an increase of the cliff height and a narrowing of the beach to circa. $10 \mathrm{~m}$ wide. A forest cover occupies the backshore. Zone $\mathrm{C}$ is quite different than Zone B except for the cliff height which reaches $6.2 \mathrm{~m}$. The sandy unit overlaying the basal unit is almost absent and the orstein unit is absent. Here, the inland vegetation is herbaceous. The cliff height at Zone D reaches $11.2 \mathrm{~m}$ and is predominantly formed of the basal silt-clay unit followed by the sandy unit. Here, the beach is $15 \mathrm{~m}$ wide. The backshore is occupied by a forest cover which borders a peat bog.

ZONE A
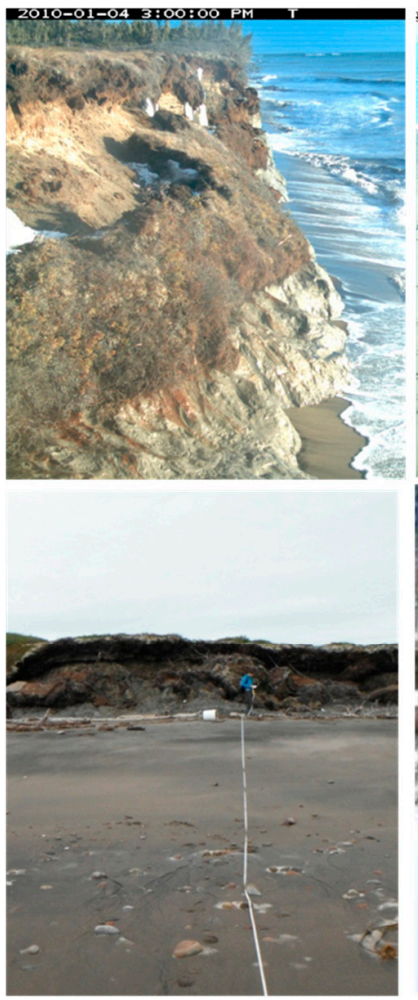

ZONE B
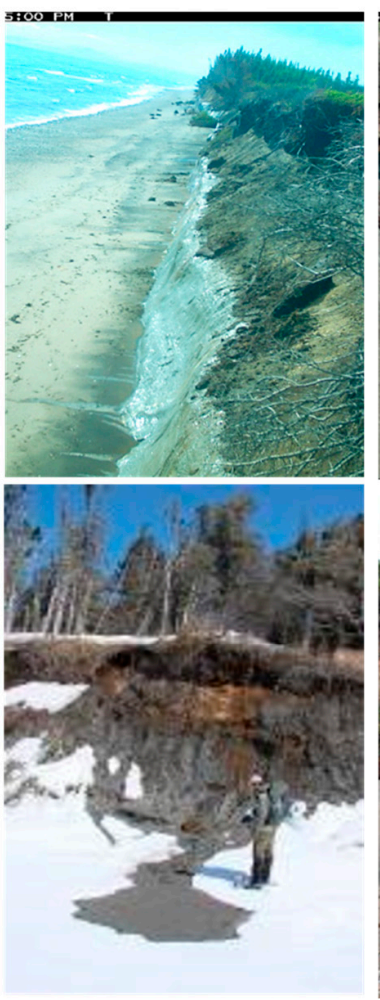

ZONE C
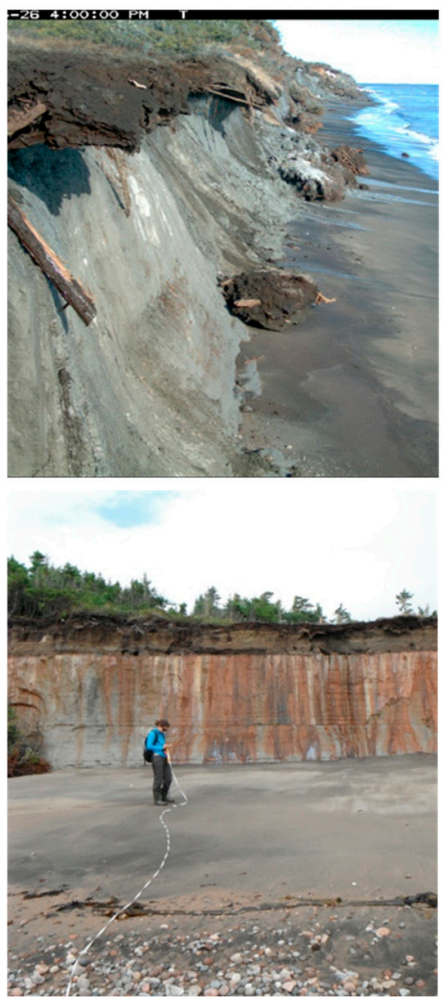

ZONE D
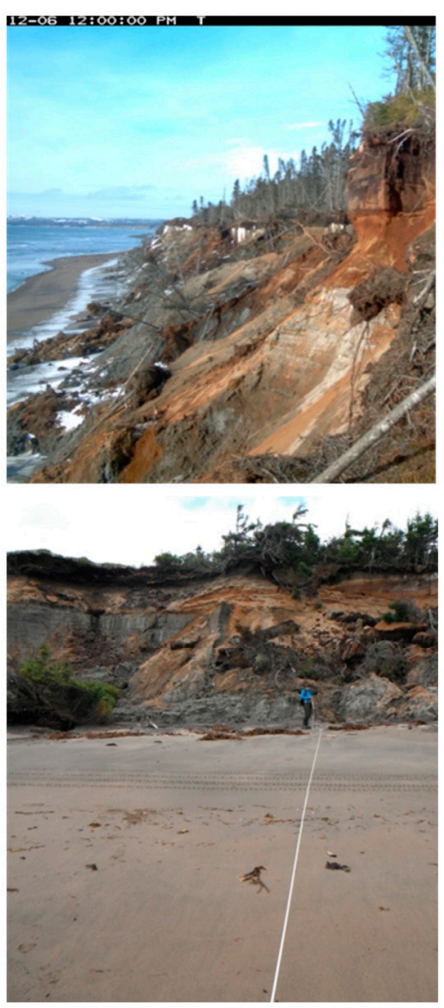

Figure 3. Monitoring zones at Rivière Saint-Jean, Québec. The upper images are from fixed cameras and lower images are the corresponding pictures taken in the field. 
Table 1. Geographic positioning and sampling frequency of the surveillance cameras.

\begin{tabular}{|c|c|c|c|c|c|c|c|}
\hline Camera & Latitude & Longitude & $\begin{array}{l}\text { Direction } \\
\text { View }\end{array}$ & Recording Start & Recording End & $\begin{array}{l}\text { Recording } \\
\text { Interval }\end{array}$ & Zone \\
\hline CAM1 & 50.292749 & -64.362216 & East & 13 December 2009 & 13 October 2010 & 30 or $60 \mathrm{~min}$ & A \\
\hline CAM2 & 50.291934 & -64.360167 & West & 12 November 2011 & 14 February 2013 & $15 \mathrm{~min}$ & B \\
\hline CAM3 & 50.292672 & -64.362304 & East & 5 December 2008 & 5 May 2009 & $60 \mathrm{~min}$ & A \\
\hline CAM4 & 50.292749 & -64.362216 & West & 5 December 2008 & 5 May 2009 & $60 \mathrm{~min}$ & A \\
\hline CAM5 & 50.290992 & -64.357863 & East & 5 December 2008 & 5 May 2009 & $60 \mathrm{~min}$ & $\mathrm{C}$ \\
\hline CAM6 & 50.286975 & -64.347768 & West & 5 December 2008 & 5 May 2009 & $60 \mathrm{~min}$ & $\mathrm{D}$ \\
\hline
\end{tabular}

Table 2. Characteristics of each zone.

\begin{tabular}{ccccccc}
\hline Zone & $\begin{array}{c}\text { Mean Height } \\
(\mathbf{m})\end{array}$ & \multicolumn{2}{c}{$\begin{array}{c}\text { Mean Beach } \\
\text { Width }(\mathbf{m})\end{array}$} & \multicolumn{3}{c}{ Unit Thickness and Relative Percentage Occupied in the Cliff } \\
\hline & & & Silt-Clay Unit & Sandy Unit & Orstein Unit & Peat Unit \\
\hline A & 4.4 & 25 & $1.54(35 \%)$ & $1.7(40 \%)$ & $0.2(5 \%)$ & $0.9(20 \%)$ \\
B & 6.0 & 10 & $2.4(40 \%)$ & $2.4(40 \%)$ & $0.6(10 \%)$ & $0.6(10 \%)$ \\
C & 6.2 & 10 & $5.3(85 \%)$ & $0.6(10 \%)$ & $0(0 \%)$ & $0.3(5 \%)$ \\
D & 11.2 & 15 & $7.3(65 \%)$ & $2.2(20 \%)$ & $0.6(5 \%)$ & $1.1(10 \%)$ \\
\hline
\end{tabular}

The cameras were fixed on a horizontal pole at the top of the cliff (Figure 4), so the acquired pictures were a profile view of the cliff covering about 30 to $40 \mathrm{~m}$ alongshore, where reliable information could be observed (Figure 3). Images were recorded every 15,30 , or $60 \mathrm{~min}$ (Table 1) over the period of study. The images were used to interpret environmental conditions and erosional characteristics across the study site (Table 3). Additional meteorological data (Table 4) were acquired from stations in Havre-Saint-Pierre, $60 \mathrm{~km}$ east of the study site (station numbers 7043019 and 7043020 [61]), and solar radiation was measured on site with a Li-cor pyranometer (LIS200S).

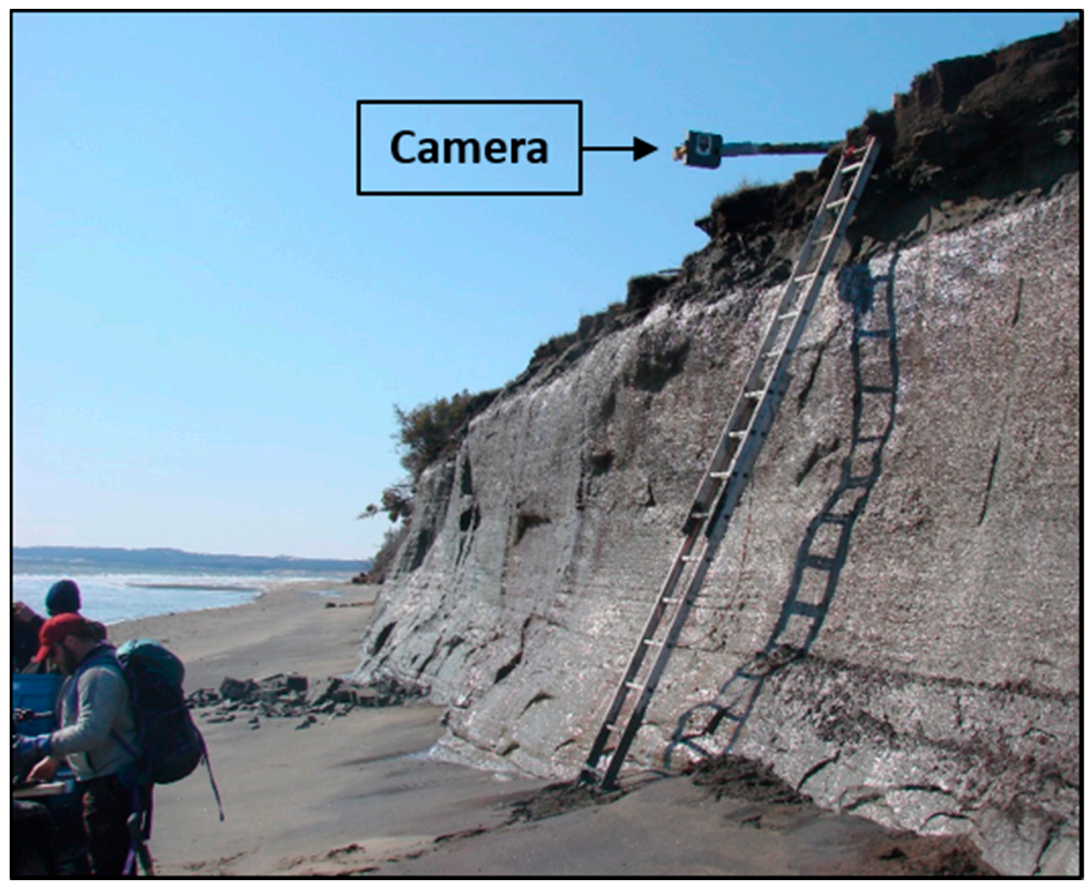

Figure 4. Camera fixed on a horizontal pole (Zone C). 
Table 3. Environmental variables observed on cameras.

\begin{tabular}{|c|c|c|}
\hline A. Identification & B. Winter Conditions & C. Hydrogeologic Conditions \\
\hline 1. Camera number & 1. Cliff snow cover $(\%)$ & 1. Surface runoff $(\mathrm{Y} / \mathrm{N})$ \\
\hline 2. Disponibility $(\mathrm{Y} / \mathrm{N})$ & 2. Ice-foot presence (Ordinal) & 2. Number of resurgences (Quantitative) \\
\hline 3. Date & 3. Ice at peat-orstein junction $(\mathrm{Y} / \mathrm{N})$ & 3. Resurgences intensity (Ordinal) \\
\hline 4. Hour (if erosion) & 4. Ice at sand-silt junction $(\mathrm{Y} / \mathrm{N})$ & 4. Snow melting $(\mathrm{Y} / \mathrm{N})$ \\
\hline 5. General comments & $\begin{array}{l}\text { 5. Ice on cliff sediment surface }(\mathrm{Y} / \mathrm{N}) \\
\text { 6. Visible melting signs }(\mathrm{Y} / \mathrm{N})\end{array}$ & 5. Visible desiccation signs $(\mathrm{Y} / \mathrm{N})$ \\
\hline D. Erosion & E. Processes by unit & F. Environmental factors \\
\hline 1. Cliff-top retreat $(\mathrm{Y} / \mathrm{N})$ & 1. Silt-clay (Qualitative, nominal) & 1. Storm waves $(\mathrm{Y} / \mathrm{N})$ \\
\hline 2. Cliff-face retreat $(\mathrm{Y} / \mathrm{N})$ & 2. Sand (Qualitative, nominal) & 2. Spring tides $(\mathrm{Y} / \mathrm{N})$ \\
\hline 3. Beach erosion $(\mathrm{Y} / \mathrm{N})$ & 3. Orstein (Qualitative, nominal) & 3. Heavy rainfall $(\mathrm{Y} / \mathrm{N})$ \\
\hline 4. Beach accretion $(\mathrm{Y} / \mathrm{N})$ & 4. Peat (Qualitative, nominal) & 4. Rainfall $(\mathrm{Y} / \mathrm{N})$ \\
\hline 5. Beach recovery by sea (\%) & & 5. Solar radiation $(\mathrm{Y} / \mathrm{N})$ \\
\hline 6. Water level relative to cliff height $(\%)$ & & 6. Rainfall-sunshine alternation $(\mathrm{Y} / \mathrm{N})$ \\
\hline \multirow[t]{2}{*}{ 7. Observed $(\mathrm{Y} / \mathrm{N} \rightarrow$ night $)$} & & 7. Inland snow melting $(\mathrm{Y} / \mathrm{N})$ \\
\hline & & 8. Gravity $(\mathrm{Y} / \mathrm{N})$ \\
\hline
\end{tabular}

Table 4. Climatic variables included in the database.

\begin{tabular}{|c|c|c|}
\hline A. Temperature $\left(\mathrm{T}^{\circ}\right)$ & B. Precipitations & C. Other \\
\hline 1. Thawing degree days & 1. Rainy precipitation & 1. Speed of maximal gust \\
\hline $\begin{array}{l}\text { 2. Sum of thawing degree days (the four } \\
\text { prior days }+ \text { the current day) }\end{array}$ & $\begin{array}{l}\text { 2. Sum of rainy precipitation (the four prior days } \\
+ \text { the current day) }\end{array}$ & 2. Direction of maximal gust \\
\hline 3. Freezing degree days & $\begin{array}{l}\text { 3. Maximal rainy precipitation in } 24 \mathrm{~h} \text { (in the } \\
\text { four prior days }+ \text { the current day) }\end{array}$ & 3. Theoretical frost front depth ${ }^{2}$ \\
\hline $\begin{array}{l}\text { 4. Sum of freezing degree days (the four } \\
\text { prior days + the current day) }\end{array}$ & $\begin{array}{l}\text { 4. Mixed precipitation (must contain liquid } \\
\text { precipitations) }\end{array}$ & 4. Maximal global solar radiation \\
\hline $\begin{array}{l}\text { 5. Cumulated freezing degree days since } \\
1 \text { October }\end{array}$ & $\begin{array}{l}\text { 5. Sum of mixed precipitation (the four prior } \\
\text { days + the current day) }\end{array}$ & \\
\hline 6. $\mathrm{T}^{\circ} \min$ & $\begin{array}{l}\text { 6. Maximal mixed precipitation in } 24 \mathrm{~h} \text { (the four } \\
\text { prior days + the current day) }\end{array}$ & \\
\hline 7. $\mathrm{T}^{\circ} \mathrm{moy}$ & 7. Standardized precipitation index ${ }^{1}$ (7 days) & \\
\hline 8. $\mathrm{T}^{\circ} \max$ & 8. Standardized precipitation index ${ }^{1}$ (14 days) & \\
\hline 9. Daily amplitude of $\mathrm{T}^{\circ}$ & 9. Standardized precipitation index ${ }^{1}$ (1 month) & \\
\hline \multicolumn{3}{|l|}{ 10. Direction (warming or cooling) } \\
\hline \multicolumn{3}{|l|}{ 11. Positive-negative $\mathrm{T}^{\circ}$ passage $(\mathrm{Y} / \mathrm{N})$} \\
\hline \multirow{2}{*}{\multicolumn{3}{|c|}{ 12. Sum of positive-negative $\mathrm{T}^{\circ}$ passage }} \\
\hline & & \\
\hline
\end{tabular}

${ }^{1}$ Calculated for a station as: SPI (for $\mathrm{n}$ days) = precipitation ( $\mathrm{n}$ current days)—precipitation (for $\mathrm{n}$ days in average) $/ \sigma$. Require at least 30 years of data for the average and standard deviation calculation [66]. ${ }^{2}$ Modified from Bergreen equation [67]: $z=13.15 \cdot \lambda\left[\frac{k_{u \cdot n \cdot F I}}{L}\right]^{0.5}$, where $\mathrm{z}=$ frost front depth $(\mathrm{m}), k_{u}=$ unfrozen thermal conductivity $\left(\mathrm{W} / \mathrm{m}{ }^{\circ} \mathrm{C}\right), n=$ surface correction factor for $F I, F I=$ freezing index (cumulated freezing degree days) $L=$ specific volumetric latent heat of fusion $\left(\mathrm{kJ} / \mathrm{m}^{3}\right), \lambda=$ correction coefficient [68].

\subsection{Wave Climate and Storm Analysis}

In order to explain the evolution of the cliff retreat rates, the offshore wave climate was investigated. A global wave model (WaveWatch III ${ }^{\circledR}$; [69]) was implemented for the whole St. Lawrence Estuary and Gulf over a $1 \mathrm{~km}^{2}$ grid $[70,71]$. The time series of wave parameters (height, period), water levels and ice concentration for the nearest point off the Saint-Jean River coast were extracted from the model for the 1980-2020 period (no data before 1980, nor for between 2018 and 2019). The point corresponds to the closest location of an AWAC (acoustic wave and current profiler) mooring (14 $\mathrm{m}$ depth), which has been used to validate the wave model. Over the whole period, the 95th and 99th percentile of wave height is $1.52 \mathrm{~m}$ and $2.33 \mathrm{~m}$ respectively.

A storm detection was performed over the same time intervals used for cliff evolution: 1980-1983, 1983-1989, 1989-1997, 1997-2005, 2005-2017, and 2000-2020. However, the 
period from 1948 to 1980 was not covered due to the lack of wave data. A threshold approach allows identifying each storm event and its characteristics. A storm is detected when the wave height exceeds the 99th percentile, and the storm duration is the time interval through which the wave exceeds the 95th percentile [72].

\subsection{Definition of Seasons}

To assess erosion processes according to seasonal climatic variables, we have defined the season periods using daily minimal, mean, and maximal temperatures, after Bernatchez et al. [73]. The year has been defined in six seasonal periods. Summer is characterized by the absence of freezing. Early fall (Fall A) begins when temperatures drop below $0{ }^{\circ} \mathrm{C}$ for the first time. Late fall (Fall B) begins when mean air temperatures drop below $0{ }^{\circ} \mathrm{C}$. Winter begins when the cumulative sum of maximal daily temperature of the subsequent deviation from $0{ }^{\circ} \mathrm{C}$ threshold remains negative. Early spring (Spring A) begins when the prevailing maximal air temperatures are positive (defined as the cumulative sum of maximal daily temperature of the subsequent deviation from the $0{ }^{\circ} \mathrm{C}$ threshold remaining positive). Late spring (Spring B) begins when mean temperatures exceed $0{ }^{\circ} \mathrm{C}$. Following the above characterization, frost action during fall is typically superficial, and during winter, frost typically penetrates the sediment $[52,74,75]$.

\section{Results}

\subsection{Multidecadal to Annual Erosion Rates}

The average erosion rate calculated from historical aerial photographs for the whole study site was $2.2 \mathrm{~m}$ per year between 1948 and 2017. Erosion rates continuously increased from the 1980s to 2017 and the two recent intervals (1997-2005 and 2005-2017) recorded the highest rates of areas land loss seen throughout the historical period (Figure 5). Highest erosion rates were seen in Zone D where up to $220 \mathrm{~m}$ of cliff retreat occurred since 1948. Between 1997 and 2017, the average annual cliff retreat rate was respectively $2.6 \mathrm{~m}$ per year, $3.3 \mathrm{~m}$ per year, $4.0 \mathrm{~m}$ per year, and $4.2 \mathrm{~m}$ per year for zones $\mathrm{A}, \mathrm{B}, \mathrm{C}$, and D.

Based on 46 coastal erosion measurement stations for the study area (Figure 1), the average rate of retreat between 2000 and 2020 was 3.30 m per year (Figure 6). The periods of 2000-2010 and 2010-2020 were comparable in terms of mean retreat rate with respective values of $3.3 \mathrm{~m}$ per year and $3.2 \mathrm{~m}$ per year. The average annual erosion values allow to observe a great temporal variability between years with a maximum average retreat value of $7.50 \mathrm{~m}$ (2016-2017) and a minimum average retreat value of $1.12 \mathrm{~m}$ (2011-2012).

\subsection{Processes Involved in Daily and Seasonal Erosion}

\subsubsection{Zone A}

Erosional activity was recorded on 71 days out of the total 396 days of monitoring in Zone A. More than $71 \%$ of the erosion events observed occurred in winter and early spring. The basal silt-clay unit was the most frequently eroded unit (Figure 7) and experienced greatest erosion during winter and early spring. Suffosion was observed only in the sandy unit in the summer and spring. The retreat of the basal units leads to the collapse of peat overhang and orstein blocks more commonly during summer and early fall. Dominating erosive processes of Zone A included solifluction, wave action, and thermoabrasion. We distinguish between the erosion processes associated with wave action only, and with thermoabrasion, the latter process involving the combined effect of mechanical and thermal energy of waves against the cliff toe when the sediments are frozen. Wave action erosion was observed predominantly in fall, before the sediment froze. During the observation period, these processes resulted in a mean cliff retreat of $1.3 \mathrm{~m}$ per year. 


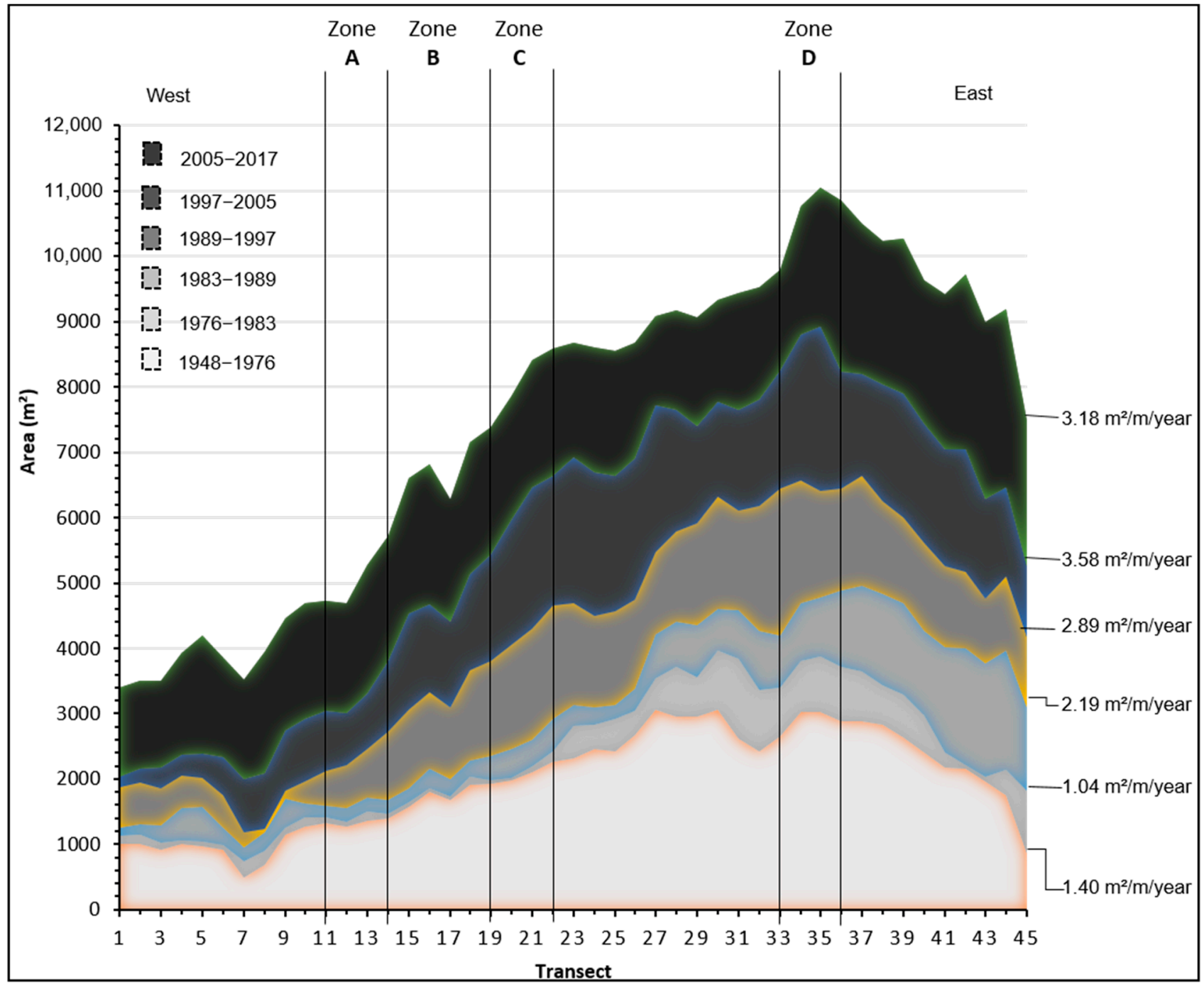

Figure 5. Cumulative historical eroded area and mean retreat rates.

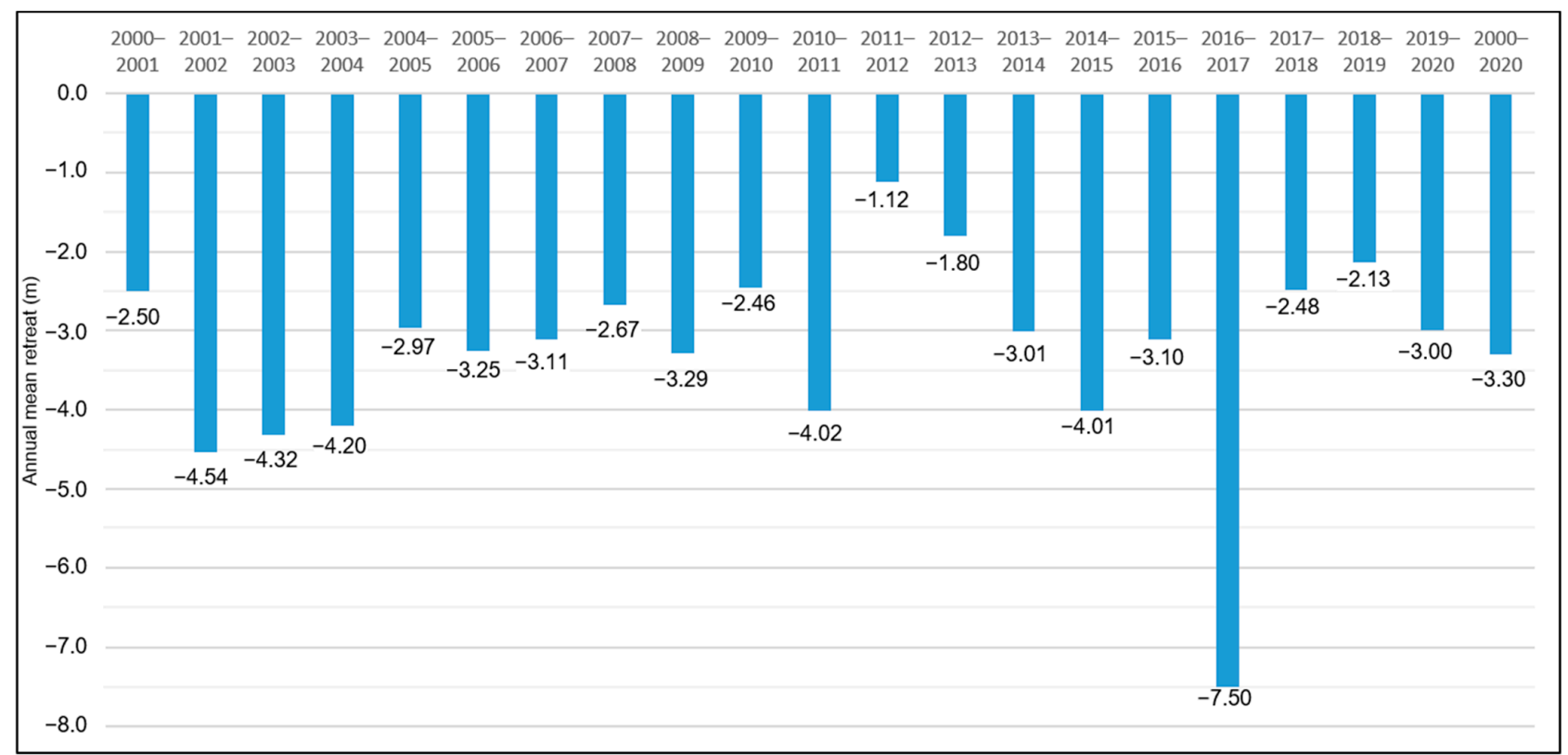

Figure 6. Annual mean retreat values (2000-2020). 


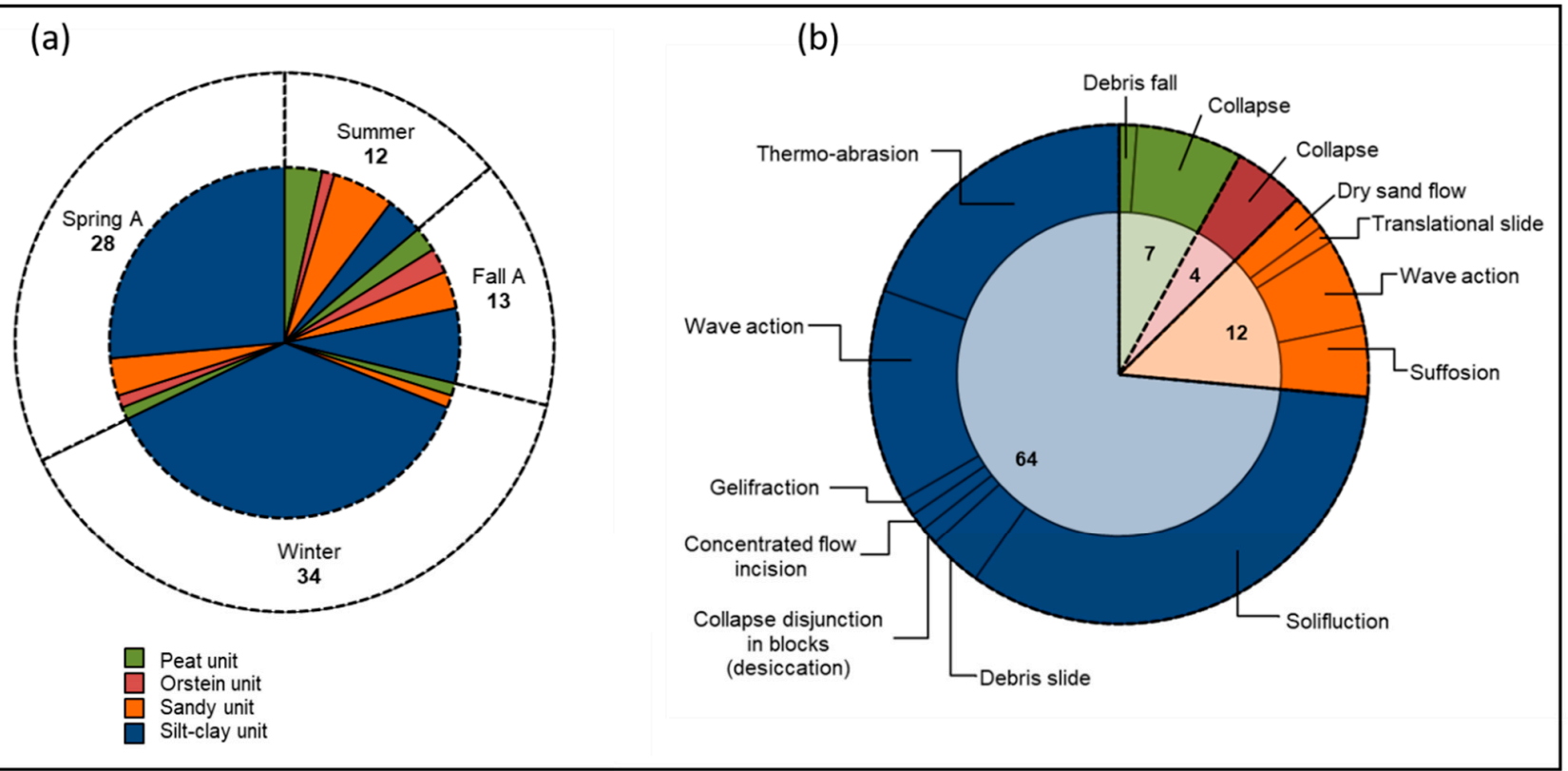

Figure 7. Number of events per lithological unit per season (a), and processes affecting the different lithologies in Zone A (b).

\subsubsection{Zone B}

Erosive activity was recorded on 80 days out of the 506 days of monitoring period in Zone B. Of the observed erosion events, $77 \%$ occurred in winter and spring. Erosional events were concentrated within the basal silt-clay unit during winter and late spring (Spring B) (Figure 8). The dominant erosive processes included gelifraction, solifluction, mudflow, and thermoabrasion. Suffosion was also important in the sandy unit during spring and fall. Peat was principally affected by debris fall and orstein by block collapse. During the observation period, these processes resulted in a mean cliff retreat of $1.7 \mathrm{~m}$ per year.

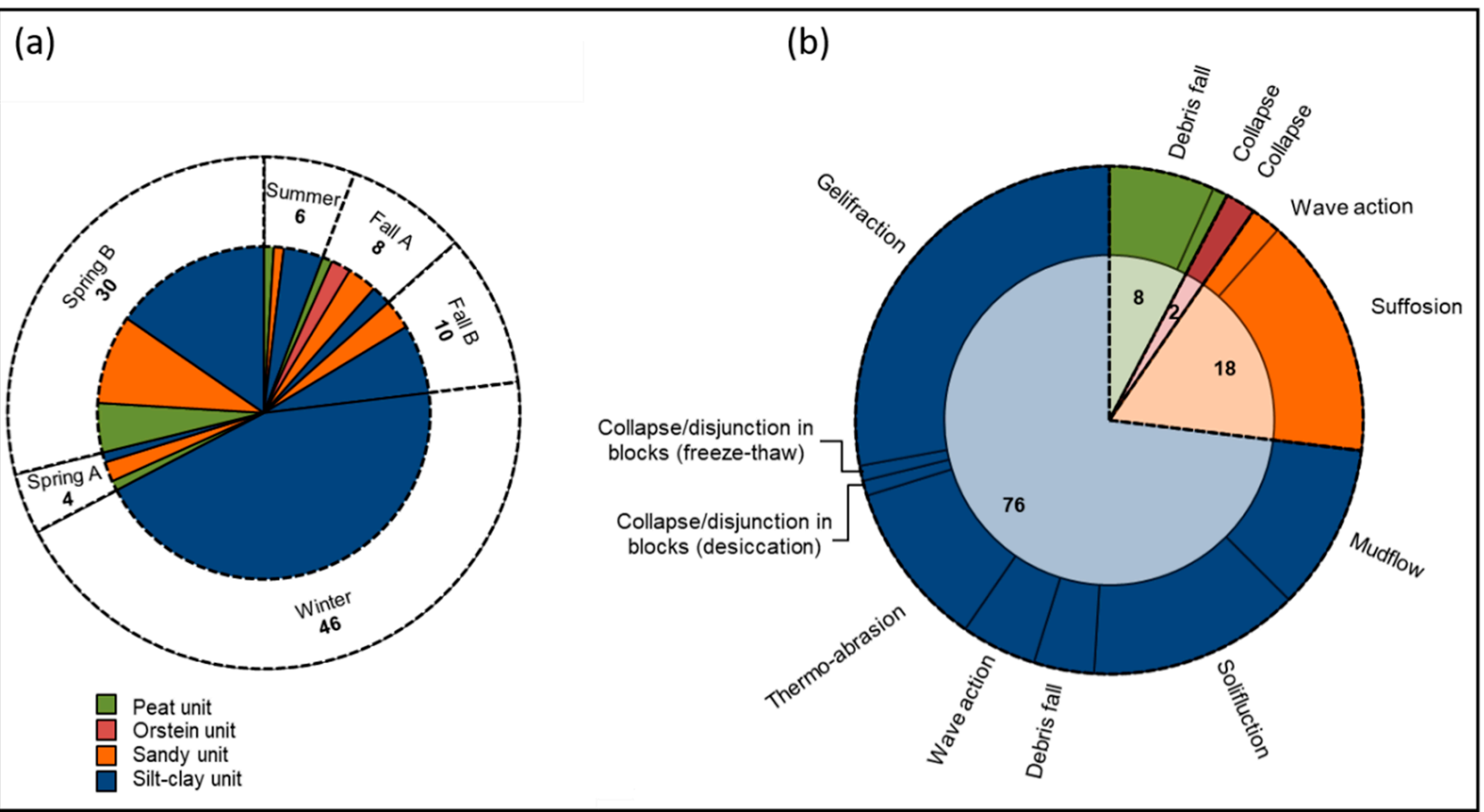

Figure 8. Number of events per lithological unit per season (a), and processes affecting the different lithologies in Zone B (b). 


\subsubsection{Zone C}

Erosive activity was recorded on 49 days out of a total 116 days of monitoring at Zone C. However, data was only collected during winter and spring. The basal silt-clay unit experienced the greatest erosion, most commonly from gelifraction, mudflows, and solifluction (Figure 9). The rapid retreat of the basal unit caused the formation of peat overhang, then its collapse was predominantly observed during late spring. During the observation period, these processes resulted in a mean cliff retreat of $2.8 \mathrm{~m}$ per year.

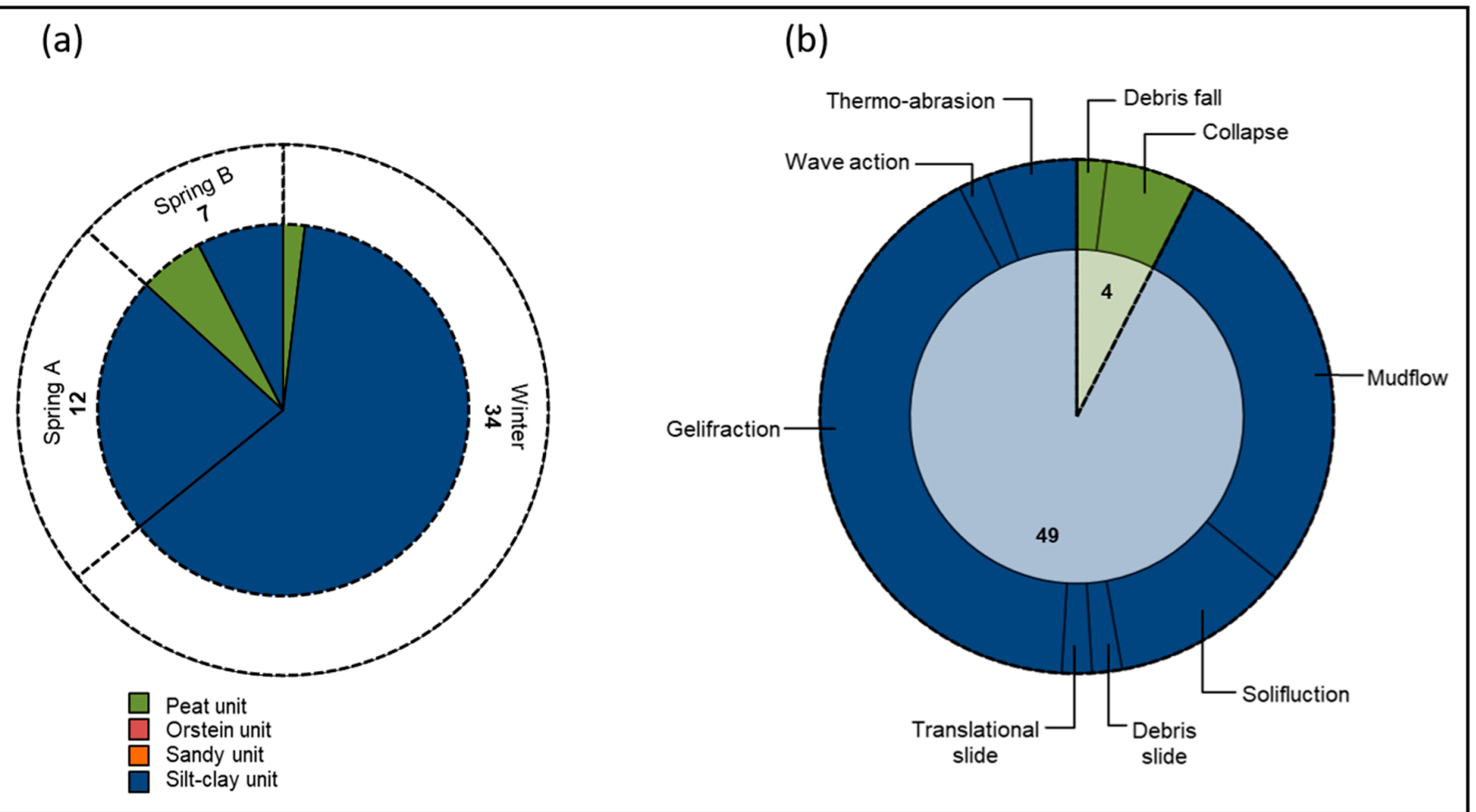

Figure 9. Number of events per lithological unit per season (a), and processes affecting the different lithologies in Zone C (b).

\subsubsection{Zone D}

On the 145 days of monitoring (winter and spring A-B only), 34 contained at least one erosion event. Unlike the other areas, it was further eroded during the first part of the spring, and the most affected lithology was the sand unit (Figure 10). Suffosion was the prevailing process, which was also responsible for the higher amount of orstein fall and collapse comparatively to the other zones. The debris and peat and orstein blocks that fell at the foot of the cliff explain why the thermoabrasion and erosion by waves were not observed. The silt-clay unit was primarily affected by gelifraction, but also by mudflows and landslides. During the observation period, these processes resulted in a mean cliff retreat of $1.9 \mathrm{~m}$ per year.

\subsubsection{Synthesis of the Seasonal Distribution of Geomorphological Processes}

Zones A and B were monitored throughout the year, which allows for the seasonal distribution of erosion events to be quantified. Of a total of 191 erosion events, $75 \%$ occurred in winter $(42 \%)$ and spring $(33 \%), 9 \%$ in summer and $16 \%$ in fall. Cryogenic processes represent $68 \%$ of the erosion events observed. Slides (without freezing) and wave action (without freezing) account respectively for $8 \%$ and $13 \%$ of erosion events. Suffosion accounts for $11 \%$ of events observed, of which the majority of events occurred in the spring $(67 \%)$. Although these events were not classified as cryogenic processes, it is clear that the conditions of melting snow and sediment played an important role in their triggering. 


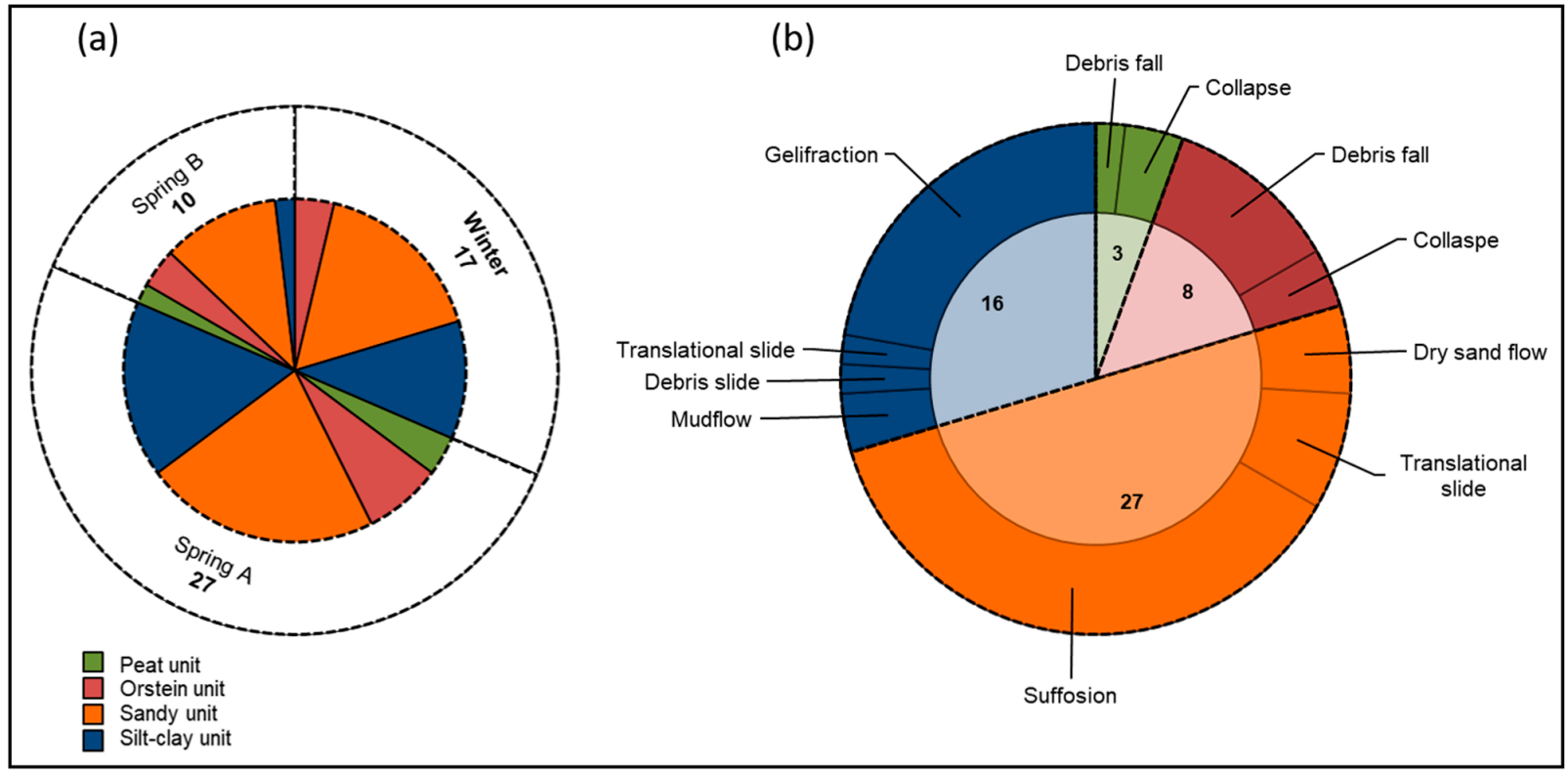

Figure 10. Number of events per lithological unit per season (a), and processes affecting the different lithologies in Zone D (b).

As the four zones were all monitored in winter and spring, it is possible to look at the distribution of the different types of geomorphological erosion processes for this period (Figure 11). Of a total of 249 events, 53\% occurred in winter, 28\% in early spring, and 19\% in late spring. It can be seen in Figure 11, that in terms of the number of events observed, gelifraction, solifluction, suffosion, thermoabrasion, mudflows, and collapses are the main geomorphological processes observed. While sub-aerial and hydrogeological processes account for $86 \%$ of events, thermoabrasion and wave action account for only $14 \%$ of events.

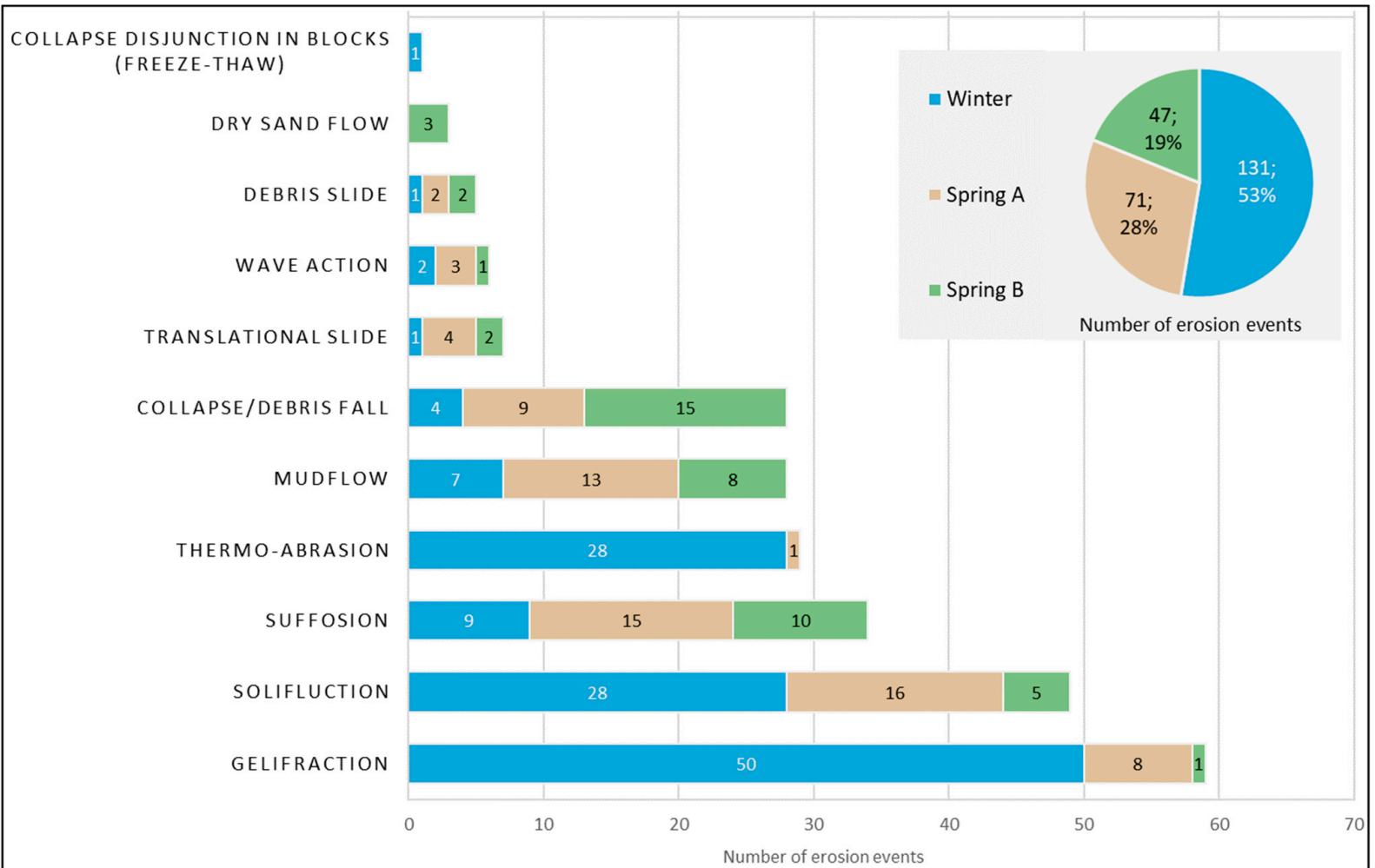

Figure 11. Seasonal distribution of geomorphological erosion processes observed by cameras in winter and spring periods. 


\section{Discussion}

\subsection{Driving Factors for Seasonal and Daily Erosion Events}

Through analyzing the daily and seasonal monitoring data with cameras, we were able to identify nine different climatic configurations that were closely related to cliff erosion (Figure 12). The majority of the erosive configurations were associated with the freezing season, in particular with freeze-thaw and melting processes. These processes are particularly efficient in the activation of silt-clay sediment [76-78] and caused high rates of erosion in our study zone.

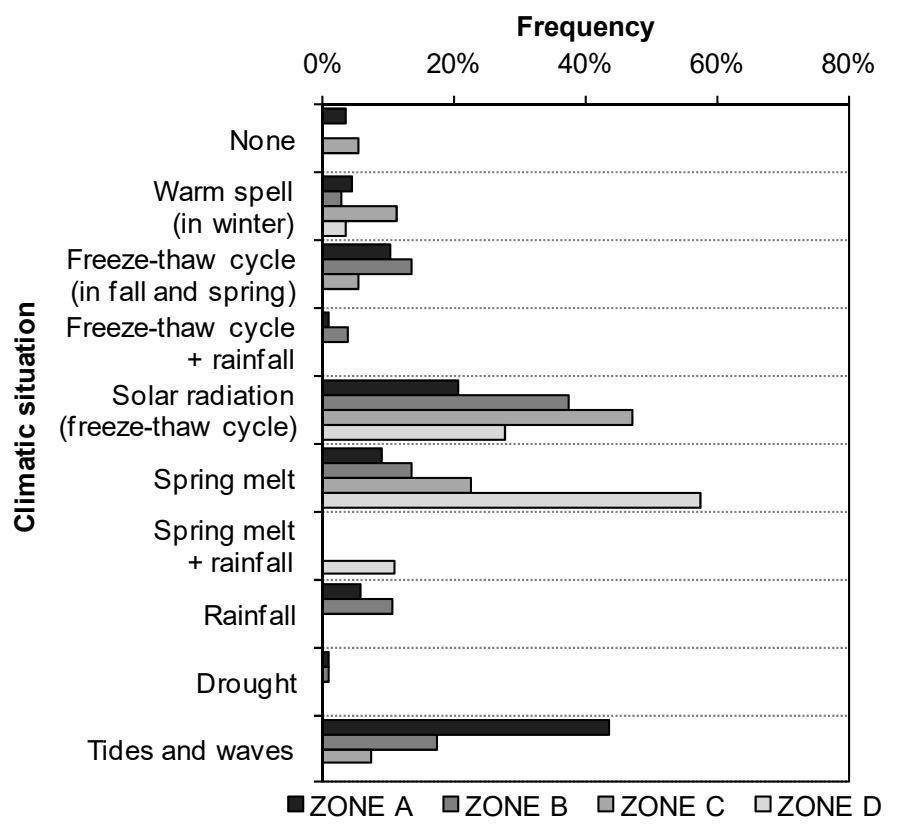

Figure 12. Climatic conditions propitious to erosion in the four monitoring zones.

Different temporal scales are found within the climatic configurations, daily, seasonal, and annual erosive cycles [75]. Daily cycles are predominantly driven by solar radiation, but also by warmer temperature variations (above $0{ }^{\circ} \mathrm{C}$ ) in late fall, winter, and early spring, and have the greatest impact on the superficial cliff surface $[74,79,80]$. The most common processes induced by the daily cycles were gelifraction, solifluction, and mudflows (Figure 13). Gelifraction and solifluction were particularly common during winter when temperatures were below freezing and global radiation was high (Figures 11 and 13) and the orientation of the southwest facing cliff promoted freeze-thaw processes [81] (Figure 14). The surface temperature can undergo large variations, and reach temperatures much higher than those of the air when the surface is exposed to solar radiation [80-82]. The dark surface and the strong composition of black minerals in the silt-clay unit can exacerbate these thermal differences and increase thermal fatigue [80], which makes this deposit particularly sensitive to gelifraction. In the absence of snow cover, vertical cliffs can register a significant number of daily freeze-thaw cycles within the first $10 \mathrm{~cm}$ to $20 \mathrm{~cm}$ of the surface [75]. In Figure $14 a-c$, we can see that despite negative air temperatures, solar radiation causes a thawing of the surface of the cliff in a few hours and activation of the solifluction processes. The effects of solar radiation on the surface and sub-surface temperature regime have above all been quantified for rocky surfaces [82], especially on hillside slopes or in alpine environments $[79,83]$. As the internal heat exchanges are linked to the thermal conductivity of the material but also to the angle of incidence of solar radiation relative to the surface, it is difficult to generalize. However, internal temperature regime measured in the silt-clay unit in the study area show that daily transfer heat is limited to the first $10 \mathrm{~cm}$ [74], which is also similar to the value of $10 \mathrm{~cm}$ reported in Daisetsu Mountains in Japan on fine soils [84]. We estimate cliff retreat associated with solar radiation between a few millimeters and 
$2 \mathrm{~cm}$ a day depending on other environmental factors, such as cloud cover, influencing local radiation levels [85]. This order of magnitude has also been measured elsewhere on the clay cliff surface [36]. Kaczmarek et al. [46] also observed weathered surfaces up to $5 \mathrm{~mm}$ thick on the face of a fine sediment bluff caused by repeated freeze-thaw cycles and dehydration. With a low magnitude but with a high frequency, these processes can still contribute significantly to the retreat of the cliff, particularly for zones $B$ and $C$ where the silt-clay unit is important and the profile of the cliff is vertical. More than $78 \%$ of gelifraction events and $57 \%$ of solifluction events occurred in winter. For the solifluction, which requires more water or humidity to occur, $43 \%$ of the events occurred in the spring, mainly in the early spring (Figures 11 and $14 \mathrm{~d}$ ). Warm climatic spells during winter are rather associated with mudflows at the study site, which allowed a greater amount of sediments to be eroded. These erosive events were not always synchronous with positive winter temperatures but occurred after a time lag of a few hours to a day, most likely related to snow melt and water penetration rates. This process was more important along the Zone $C$ where the height of the silt-clay unit is important, combined with the vertical profile of the cliff.

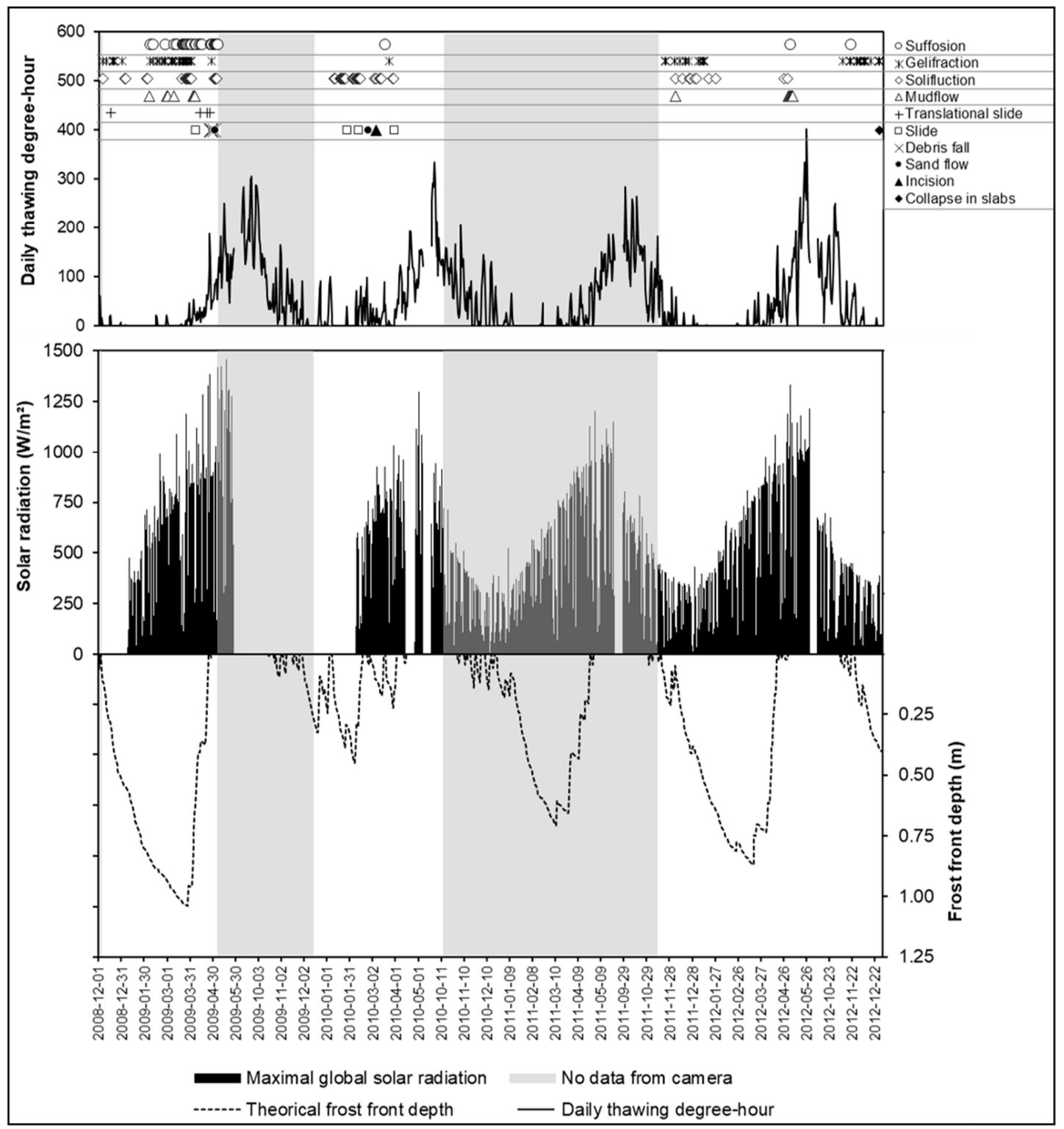

Figure 13. Chronology of the different cryogenic erosion events in relation to the processes, the daily degree hours, the solar radiation, and the frost front depth. 


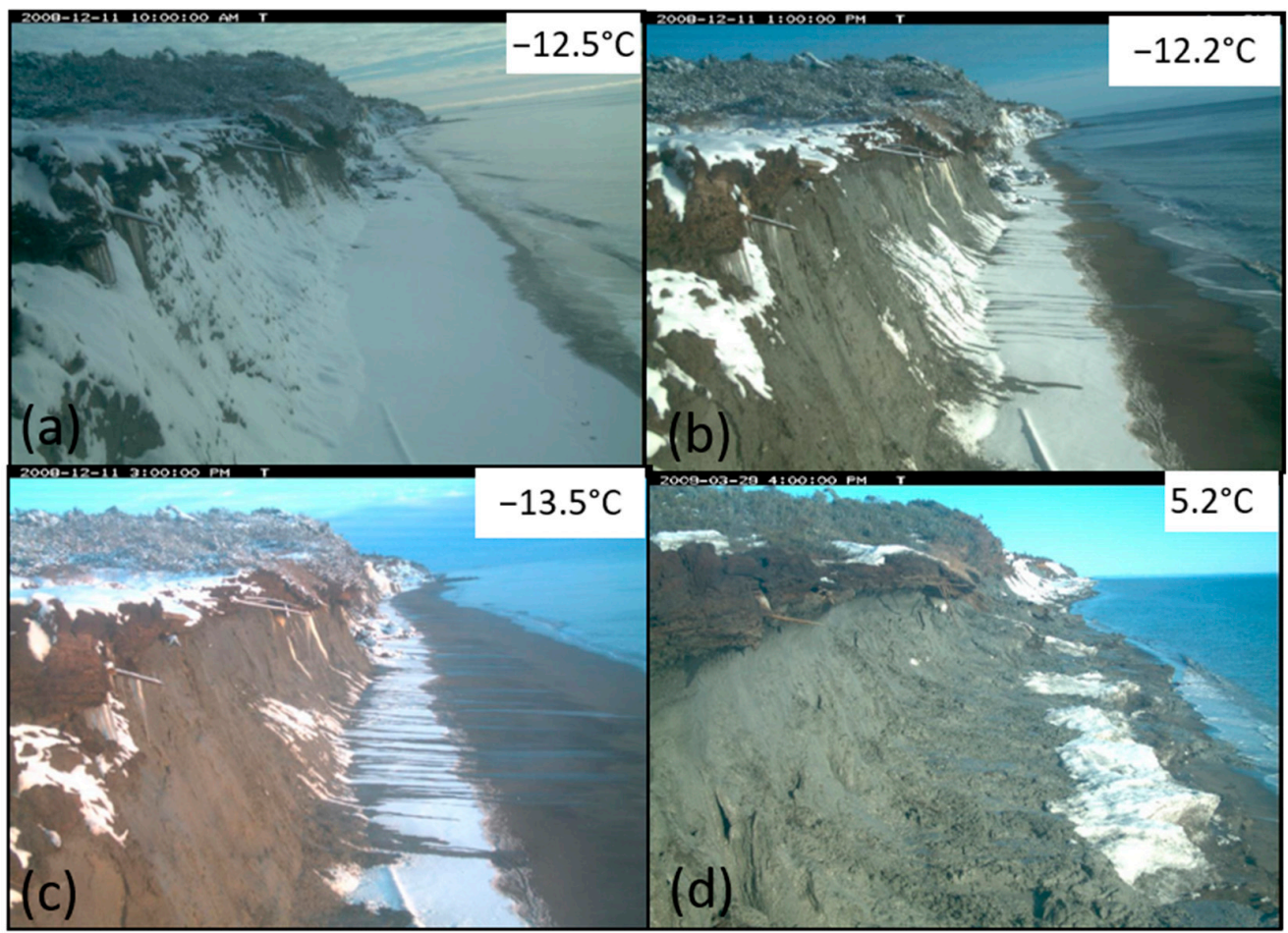

Figure 14. Impact of solar radiation on the triggering of solifluction: (a-c), 11 December 2008 at 10:00, 13:00. and 15:00 respectively; (d) 29 March 2009, active thawing and solifluction on the whole cliff. The sediments cover the ice-foot.

The annual freezing cycle was caused by the progression of a frost front into the sediments possible during late fall, winter, and early spring with cumulative freezing degree days $[52,67]$. With the lateral progression of the frost front from the cliff faces, segregation ice, and ice lenses form perpendicularly to the silt-clay unit bedding (horizontal), which causes a complete destruction of its internal structure [36,74]. The frost front can reach more than $1.0 \mathrm{~m}$ deep in the silt-clay unit (Figure 13; [52]). With the complete melting of segregation ice in the spring, sediments are eroded gradually following the thawing front and significantly contributing to cliff retreat. The total annual cliff retreat associated with this process corresponds to the maximum annual depth reached by the frost front $[52,74]$. Similar results have also been observed in other lithologies where the intense rockfall activity is associated with the penetration of a thawing front in frozen sediment rather than with diurnal freeze-thaw events or precipitation [86]. As a result, the frequency of the events number reached a maximum in early spring and lead to a rapid cliff retreat with the occurrence of numerous processes (Figure 13). As Boucher-Brossard et al. [52] have shown on the north shore of the St. Lawrence, the maximum annual depth reached by the frost wave can also be increased by winter warm-spell events. They cause the retreat of the silt-clay surface of the cliff, which instantly reduces the distance between the cliff surface and the frost front, and thus allowing the frost wave to continue its progression at depth. Subsequently, warm-spell effects can contribute to an additional $50 \mathrm{~cm}$ of sediment freezing and erosion by the end of the cold season [52]. The depth of the frost wave can also be strongly influenced by the snow distribution pattern in the cliff [47]. With high albedo and insulating capacity, the snow reduces surface heat exchange and reduces the penetration of the frost wave [82,87]. It also reduces the daily freeze-thaw cycles associated with solar radiation and therefore can minimize frost shattering (Figure 15a) [74]. Thus, the processes associated with freezing were particularly effective where the silt-clay surface of the cliff was free of snow for much of the winter. 


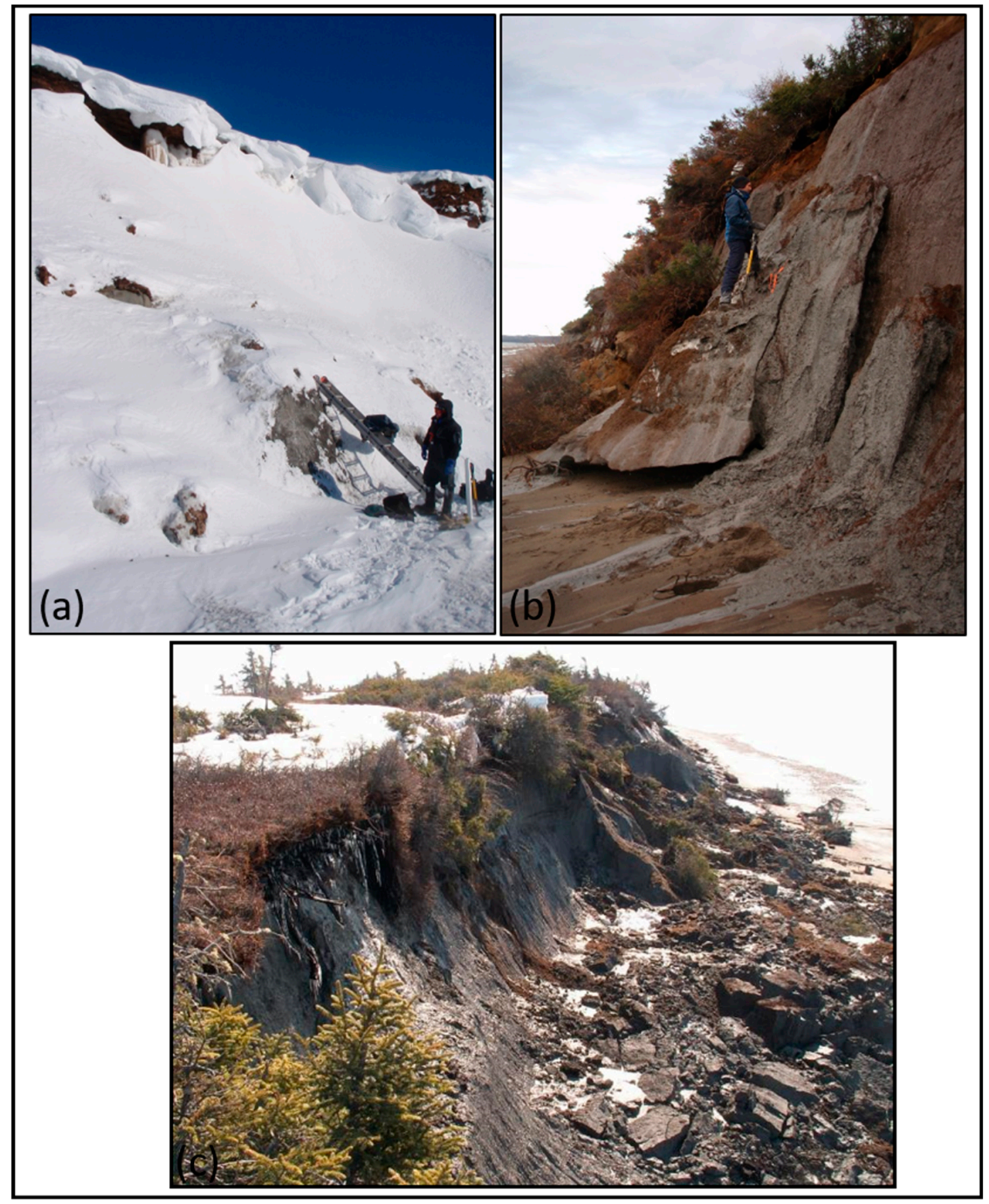

Figure 15. (a) Snow cover on the cliff protecting against daily thermal variations, 10 February 2009; (b) detachment of a slab at the contact between frozen and unfrozen sediments, 26 April 2009; (c) translational slide caused by vertical shear surface.

Another important element associated with the peculiarity of a vertical frost front bordering cliffs with seasonal frost is that the discontinuity surface between frozen and unfrozen sediments forms a vertical shear surface. This shear surface generates the detachment and the collapse or the slide of silty clay blocks and slabs [36] (Figure 15b,c). The retreat can occur at different times during the winter so that the size of the blocks or slabs will increase with the penetration of the frost wave, which generally reaches its maximum depth at the end of March for our area of study (Figure 13). Matusuoka and Sakai [86] also observed that freeze-thaw depth seems to control the maximum size of the blocks that break off during rock mass detachment on alpine slopes. Others have shown that the size 
of blocks can also be determined by geological structures or by stress-release joints [88]. Tension cracks formed by the freeze-thaw process can also contribute to block failures [89].

Other erosion processes prevalent during freezing conditions included thermoabrasion caused by the heat transfer between the wave action and the frozen sediments of the cliff toe $[28,90]$ (Figure 16a). Notch formation by thermoabrasion then causes the collapse of silt-clay blocks or slabs (Figure 16b). Wilcock et al. [88] used the term spalling to describe this retreat mode. Despite the fact that thermoabrasion is a process limited in time by the presence of an ice-foot and the period of frost, and that it accounts for $12 \%$ of the erosion events observed, this process can contribute significantly to the retreat of the cliff. The analysis of the cameras allowed the observation of erosion events during all winter-spring tides when a frost wave had penetrated the sediments, except when a complete ice-foot prevented the waves to reach the cliff bottom (Figure 17). We also note that high water levels were often accompanied by strong wind events with wind speeds of over $30 \mathrm{~km} / \mathrm{h}$ (Figure 17). Other authors have also shown that winds of $30 \mathrm{~km} / \mathrm{h}$ to $40 \mathrm{~km} / \mathrm{h}$ caused significant retreat of the cliff by thermoabrasion and block failure [34]. Greenwood and Orford [91] also showed that wave erosion occurs when two main thresholds are exceeded, i.e., water levels greater than $1.5 \mathrm{~m}$ above mean sea level combined with wind speeds above $55 \mathrm{~km} / \mathrm{h}$. However, for our study area, we note that outside the frost period, wave erosive events occurred even during neap tides (Figure 17). We explain this difference by the fact that the retreat occurs when the surface of the silt-clay unit is already weakened by weathering. The silt and clay form a deposit that has high cohesive strength and is resistant to direct wave action $[36,88]$. In the absence of a surface already weakened by weathering, the direct wave action on the toe of the cliff on the silt-clay unit's retreat appears negligible.
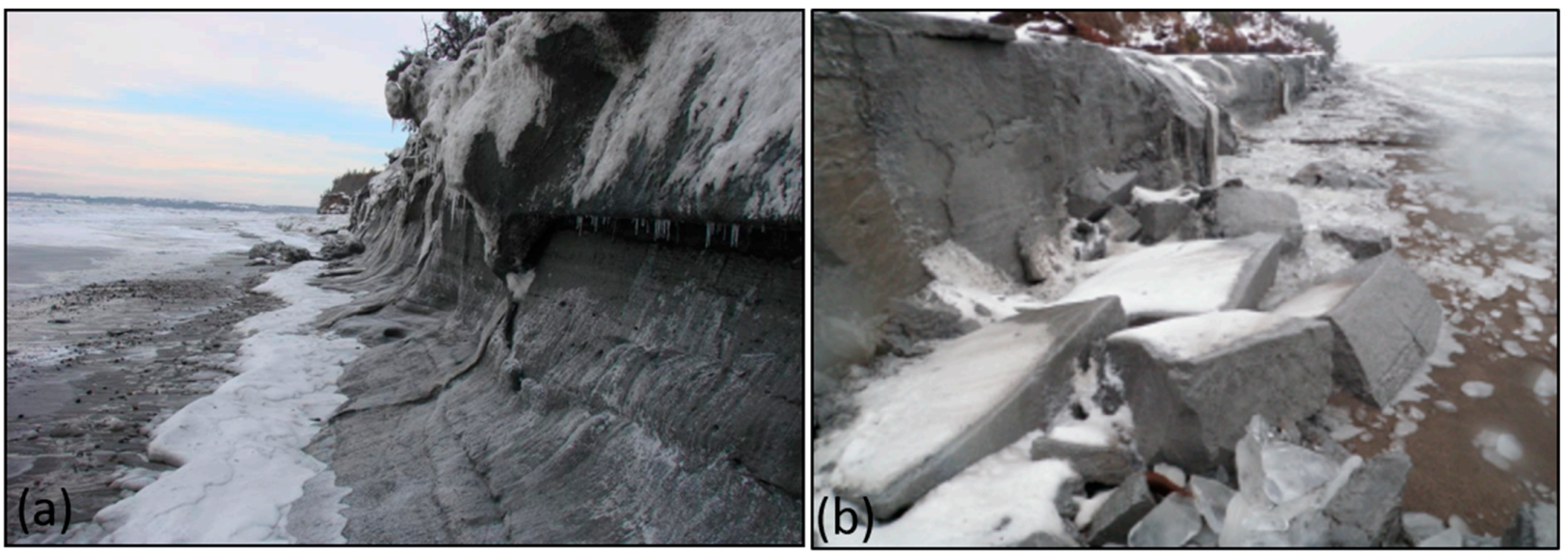

Figure 16. (a) Notch formation by thermoabrasion in December; (b) block collapse.

The spring melt period induces many erosional processes such as mudflows, solifluction, suffosion, slides, debris fall, and failure collapse. A total of $75 \%$ of mudflow events occurred in the spring when the solar radiation and daily thawing degree hours were high (Figures 11, 13 and 18a). Some of those events were accompanied by rains (21\% of events). These meteorological conditions are conducive to the rapid melting of the snow cover, which generates a significant inflow of water at the edge of the cliff, in addition to the sediments thawing in the silt-clay unit. They are therefore key factors in the liquefaction of fine sediments and the triggering of mudflows from cliffs with seasonal frost. This process could also be favored by the thawing of segregation ice lenses, leading to an increase in sediment moisture [84]. 


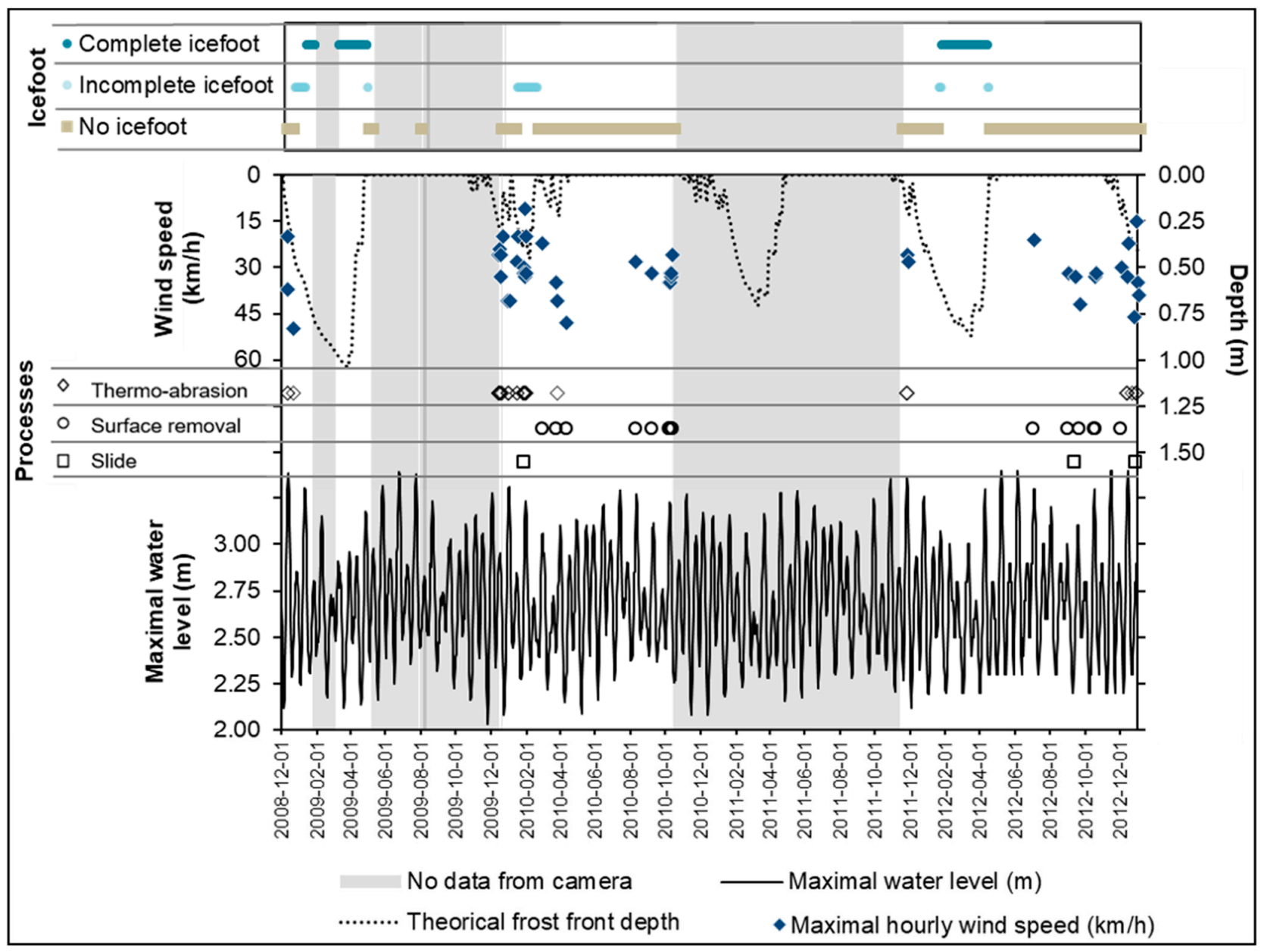

Figure 17. Chronology of the different hydrodynamic erosion events in relation to the processes, the wind speed, the tide cycle, and the frost front depth.
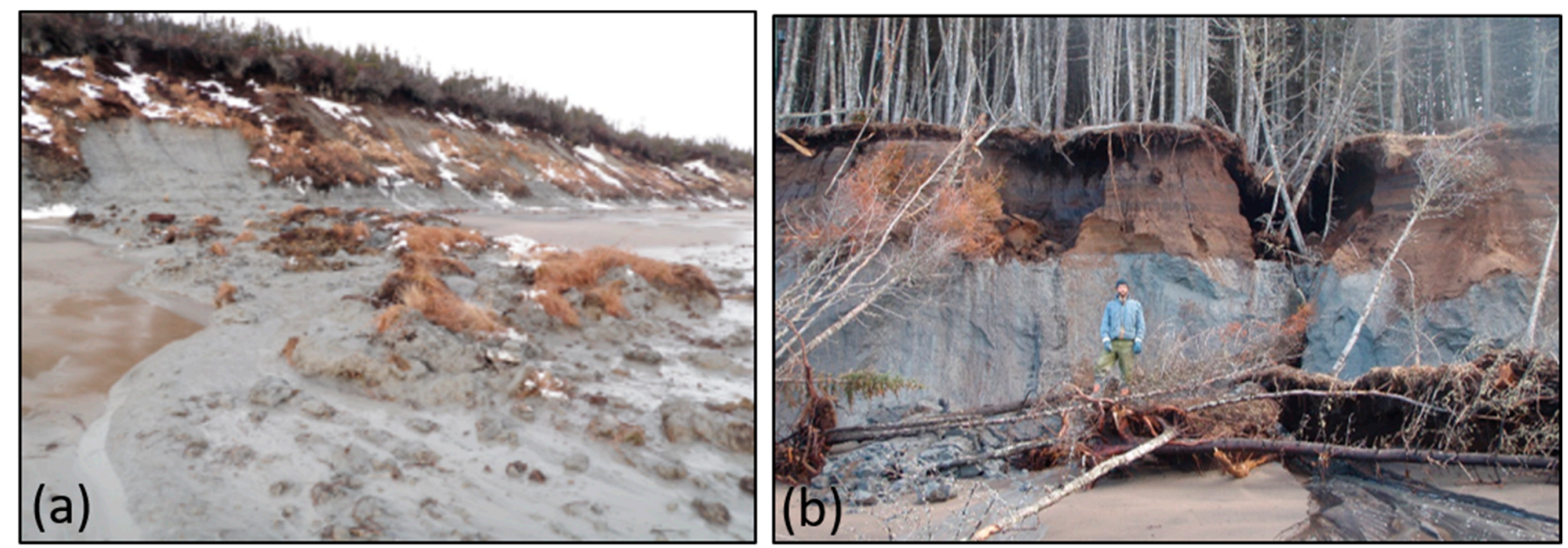

Figure 18. (a) Mudflow in April; (b) suffosion holes on the sandy unit, 26 April 2009.

With the snow melting and the sediment thawing, water penetration also induces high flow circulation into the sediments and contributes to hydrogeological erosive processes such as suffosion, seepage, and sandflow [36,89,92] (Figure 18b). These processes have the greatest influence on the upper sandy unit. The highest erosion rates of this unit were found at Zone D where the thickness of the sandy unit is the greatest relative to the cliff height. In this area, we also observed a large number of suffosion events in winter (9) and early spring (10) when the sediments were frozen to a depth of $50 \mathrm{~cm}$ to $1 \mathrm{~m}$ (Figure 13). 
As shown by Roland et al. [35], for a bluff on the shores of Lake Michigan subjected to a seasonal frost, the frost can constitute a "dammed" bluff surface, which can lead to an increase in hydraulic pressure and promote erosion of the sand unit during a warm spell. Suffosion was also not negligible for Zone B where the sand unit is also important.

Groundwater circulation was also increased by spring and fall rainfall resulting in various processes for both the silt-clay and the sandy units (Figure 19). The main processes are landslides and suffosion. Erosional events occurred following a $>30 \mathrm{~mm}$ of rainfall episode (cumulative amount for 5 days) or when the standardized precipitation index (SPI) was greater than 2. Even when these thresholds were not reached, erosion events were also caused during rainfall coinciding with spring melt. At other sites, a similar threshold of $30 \mathrm{~mm}$ rainfall within 5 days has been seen to induce erosional activity in soft rock cliffs [93-95]. Rainfall or snowmelt can increase pore pressures and cause mass failure in the cliff $[35,89]$. Contrastingly, a low SPI may indicate the onset of sediment desiccation, which can contribute to erosion when followed by heavy rainfall or wave attack $[36,91,96]$. However, erosion by desiccation processes was little observed in the study area. The continuous groundwater sheet flows in contact between the sand and silt-clay units do not favor the wetting and drying processes. Bernatchez and Dubois [36] also observed on the edge of an argillaceous cliff that desiccation was negligible along a peat bog where there was a constant inflow of water on the surface of the cliff while on the edge of a well-drained environment, the desiccation process could contribute to $20 \%$ of the total annual retreat of the clay cliff. Gaskin et al. [96] also observed that wetting and drying of clay banks of the St. Lawrence River from water-level changes and wave runup increases erosion rates. Desiccation can also occur in winter with the drying of the surface of the silt-clay unit [40]. It is favored in winter by a negative SPI, the very low vapor content of the cold air, strong winds, a strong exposure to solar radiation, as well as by the migration of water during the formation of the segregation ice. Winter desiccation can sometimes be difficult to separate from frost shattering, especially from tracking cameras.

\subsection{Causes of Spatial and Temporal Variability in Cliff Retreat Rates}

\subsubsection{Causes of Spatial Variability}

It is recognized that cliff retreat rates exhibit spatial and temporal variability [44]. Data collected in this study reveal a rapidly retreating cliff governed by a variety of processes operating on different temporal scales. Several authors have examined the effect of material properties, such as texture and shear stress [97-99], and demonstrate that lithostratigraphy has a significant impact on retreat modes and rates $[36,40,94,100]$. Our findings support this idea and show that the relative thicknesses of the two main sedimentary units, the silt-clay unit and the sandy unit, are sensitive to different types of annual retreat mode. But lithostratigraphy also varies according to the height of the cliff, which is also an important factor that has been reported to explain the rates of retreat and erosion processes [43,101].

Lower cliffs, in Zone A, with a sandy unit at less than about $2 \mathrm{~m}$ above the cliff toe-beach junction, are more affected by waves and therefore are more sensitive to hydrodynamic forcing during storms, although cryogenic and hydrogeologic processes may also play a significant role in cliff erosion. Retreat events can thus take place in all seasons. Two types of retreat mode can operate depending on the predominance of hydrodynamic or sub-aerial processes. When the silt-clay unit is eroded by cryogenic processes faster than the upper units, the top of the cliff is readjusted by gravity or hydrogeological processes. In cases of intense storms with high waves, the upper sandy unit of the cliff can be eroded at a faster speed than the cliff base because of the noncohesive nature of the sand (Figure 20a). In such cases, the cliff bottom readjusts mainly in the successive winter and spring, when frost front can penetrate the sediment both vertically and horizontally. However, the resulted shape of the cliff after a storm (in steps, see Figure 20a), combined with its lower height, promote the accumulation of snow, which may slow down erosion by limiting freeze-thaw cycles and the frost front progression (Figure 20b). Consequently, the retreat tends to be more sporadic, localized, and reduced. 


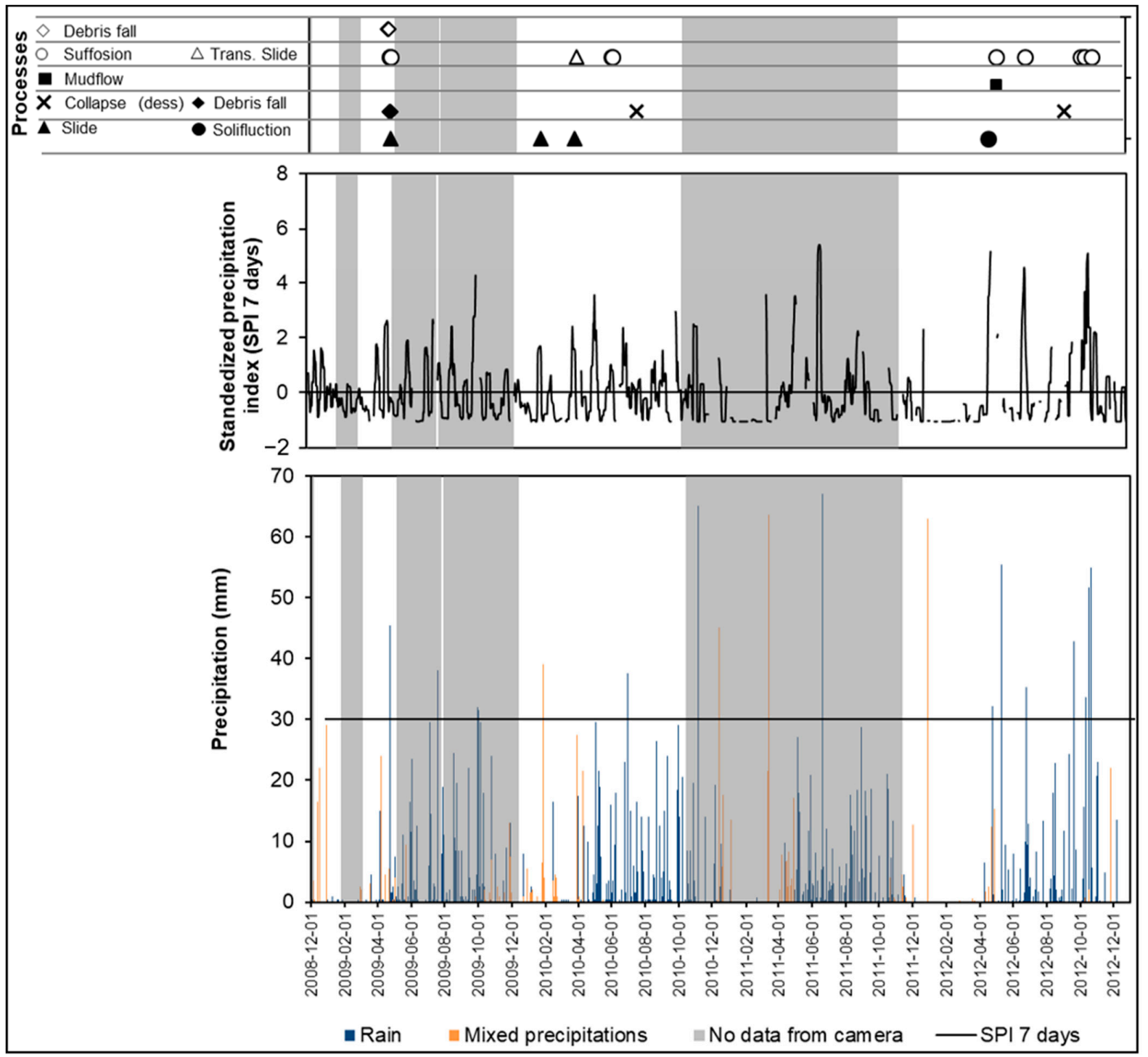

Figure 19. Chronology of the different hydrogeological erosion events in relation to the processes, precipitation events, and the standardized precipitation index (SPI) of seven days.

The increase in the thickness of the silt-clay unit from west to east from $1.5 \mathrm{~m}$ (Zone A) to $7.3 \mathrm{~m}$ (Zone D) seems above all to favor a greater intensity of cryogenic processes. Gelifraction proportionally becomes the most important process affecting the silt-clay unit as soon as its thickness exceeds more than $2 \mathrm{~m}$. It is also from this threshold that the mudflows are observed. It proportionally becomes the second most important process when the thickness of the silt-clay unit exceeds $5 \mathrm{~m}$.

Where both the silt-clay and the sandy units are thick, as observed in Zone $\mathrm{D}$, suffosion is the dominant erosion process. Water circulation at the sand/silt interface promotes suffosion and general instability of the cliff's noncohesive material, resulting in a very fast retreat speed, since high water content situations are recurrent with spring melt and more or less $830 \mathrm{~mm}$ of rainfall annually. It has also been suggested that the magnitude of the erosion caused by this process is closely linked to the thickness of the sand [53], which is another aggravating factor in this case. Moreover, the cliff maintains a steep profile because of the silty unit's exposure to freezing enables gelifraction, mudflows, and slides. In this geomorphological context, the top of the cliff recedes more quickly, leading to a more pronounced concave profile. Where there are landslide scars in the cliff face that persist until the onset of winter, snow accumulation is greater in these scars. As some authors have pointed out, snow can, on the one hand, protect against erosion 
associated with daily thermal variations, but, on the other hand, its melting in spring can promote hydrogeological processes that can lead to geomorphological processes of greater magnitude in the cliff $[47,102,103]$.
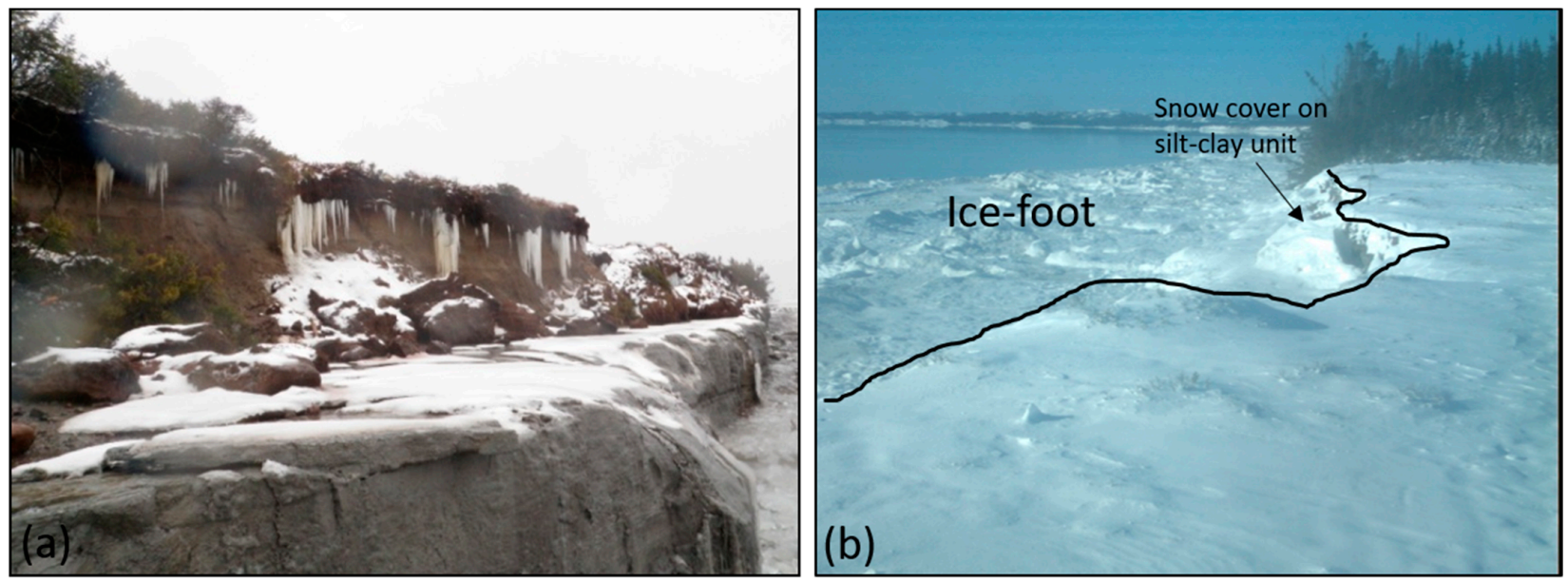

Figure 20. (a) Erosion of the sandy unit by wave sapping during a winter storm; (b) the surface of silt-clay unit is completely covered with snow, 18 January 2009. The black line corresponds to the top edge of the cliff.

Therefore, we also observe, at the historical scale, that the speed of recession rate increases with the height of the cliff and the relative increase in the thickness of the sandy and the silty clay units (Figure 21). Zone D records the higher values of cliff recession (Figure 5), even if the highest frequency erosion events observed with the cameras are associated with Zone $\mathrm{C}$. This is explained by cliff retreat of greater magnitude for the Zone $\mathrm{D}$ because of hydrogeological processes (translational landslides and suffosion). Quinn et al. [104] showed that cliffs with heights of more than $15 \mathrm{~m}$ were dominated by landslides generating greater retreat. However, we note that landslides can also occur from a cliff height of $6 \mathrm{~m}$ in our study area. Contrary to some studies on coastal landslides, which indicate that the waves are the trigger mechanism [44,105], our results rather show that they are triggered by rainfall and water supplied from melting snow [35]. Moreover, as the majority of landslide events occur in the presence of an ice-foot, waves act primarily as sediment removal agents in the spring along with the ice-foot during breakup. Some authors have observed that landslide lobes can protect the base of the cliff and ensure its stability for several years, which was not observed in our study area. As several authors have reported for the northern coasts, sediments eroded by cryogenic processes are quickly removed and evacuated [106], often in a few weeks or months, or even a few days by wave action $[12,30,31]$ or by ice-foot during break up $[7,107]$, so that the geomorphological processes in the cliff can start again rapidly. In this sense, the dynamics of cliffs in cold regions are different from the dynamics of coasts without ice cover. The speed at which sediment and debris that falls at the foot of the cliff are removed is therefore an important factor to consider to explain the cliff retreat rates. The fine texture of the sediments and their ice content partly explain the rapid evacuation of sediments by waves or high water levels. The weathered and unstructured nature of the sediments affected by cryogenic processes that fall at the foot of the cliff also favor their transport. 


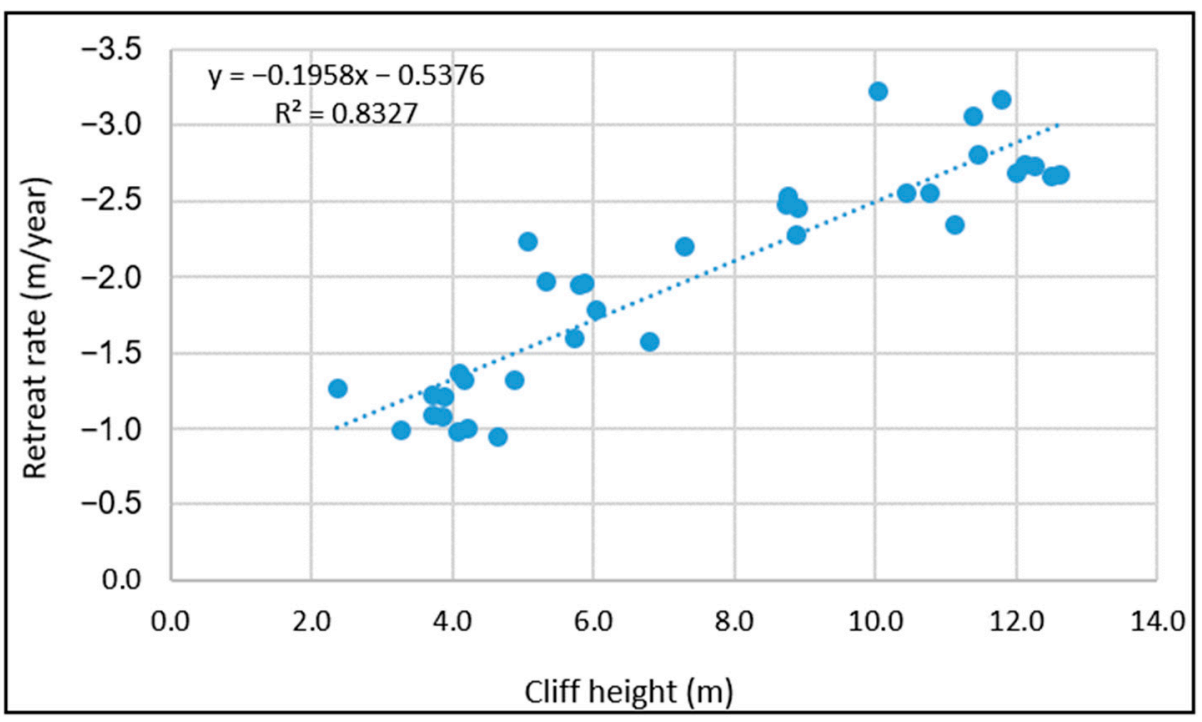

Figure 21. Relationship between retreat rates and cliff height at Rivière Saint-Jean.

\subsubsection{Causes of Temporal Variability}

With a long-term average retreat rate of $2.2 \mathrm{~m}$ per year (1948-2020) and an average rate of $3.3 \mathrm{~m}$ per year between 2000 and 2020, the study region is one of the cold regions coastlines of the world with the highest recession rates. Long-term data on the retreat rates of coasts affected by cryogenic processes come mainly from the Arctic coasts, where the average retreat rate has been estimated at $0.5 \mathrm{~m}$ per year and half of the coast segments analyzed present values less than $1 \mathrm{~m}$ per year [41]. However, values greater than $4 \mathrm{~m}$ per year have also been measured over the long term in the regions of the Kara Sea and Laptev Sea on the Russian coast [25], as well as along the Beaufort Sea [29]. In the Maritime Estuary and the Gulf of St. Lawrence, the long-term average retreat rates (over 30 years) of silt-sandy and clayey cliffs generally vary between $0.3 \mathrm{~m}$ per year and $0.8 \mathrm{~m}$ per year [7]. The results of the Rivière Saint-Jean cliff show that cliffs in temperate regions with seasonal frost can retreat as quickly, if not faster, than those in the Arctic. We can clearly observe an acceleration in the rate of retreat since the early 1980s for our study region. By comparing the data on the rate of retreat of low clay cliffs (height $<10 \mathrm{~m}$ ) in the St. Lawrence Estuary for the period before and after 1990, Bernatchez and Dubois [7] also showed an acceleration of erosion where the mean retreat rate almost doubled from $0.85 \mathrm{~m}$ per year to $1.6 \mathrm{~m}$ per year. In the Arctic, the erosion of certain coastal regions is accelerating, especially along most of the Russian coasts $[25,28,48]$ or even along coastal segments of Alaska $[29,108]$ and the Northwest Territories [23]. In the Drew Point area (Alaska), the acceleration in erosion rates is spectacular-the mean values have gone from $6.8 \mathrm{~m}$ per year (1955-1979) to $8.7 \mathrm{~m}$ per year (1979-2002) to $13.6 \mathrm{~m}$ per year (2002-2007) to $15 \mathrm{~m}$ per year $(2008-2011)$ [12,29]. However, some coastal segments show a certain long-term stability [14,32], while others also show fluctuations over time with periods of strong and weak erosion, particularly on the coasts of Yukon $[33,34,109]$, Alaska [110,111], and Siberia [17], so that it is difficult to define trends. Global warming has been identified as the main cause of accelerated erosion of cliffs in the Arctic, particularly associated with melting permafrost associated with increasing thawing degree days and increased cliff toe exposure to hydrodynamic agents with the increase in the number of ice-free days $[24,27,31]$.

Influence of Marine Forcing on Retreat Speed

In total, 164 storm events were observed for the 1980-2020 period in the study area (Figure 22). Analysis of modeled wave data does not seem to show an increase in storm events between 1980 and 2017 and does not seem to explain the acceleration of cliff erosion. Indeed, the number of storm events per year is at its lowest for the period of 1997-2005, while the rate of retreat was the highest for this period. Other studies have also shown in 
the Arctic that the number of storms does not correlate well with the rates of retreat [17,44]. Vasiliev et al., [44] show, however, for the region of the Kara Sea that despite the lack of relationship with the number of storms, the retreat rates are significantly correlated with the total wave energy. Also, on the coast of the Kara Sea, the increase of wind-wave energy flux and the duration of ice-free periods have also been suggested to explain the acceleration of coastal erosion [112]. Our results point in the same direction. When we look only at the winter period, we see that the trend of wave power rises between 1995 and 2020 (Figure 23a). This trend is correlated with the decrease of the sea ice fraction at the sea surface, which induces less wave-energy dissipation and more wind-wave energy transfer at the sea surface by extending the fetch (Figure 23b). These marine conditions could thus promote thermoabrasion and partly explain the much higher retreat rates for the period 1997-2017. Moreover, among the 52 highest storm events (i.e., when the peak of significant wave height exceeds $3 \mathrm{~m}$ ) between 1980 and 2017, 67.3\% occurred during the period 1997-2017. In addition, $62 \%$ of these events are correlated with the active period of thermal abrasion. In our study area, the basal notches caused by thermoabrasion are rarely deep compared to the permafrost coast, limited by the frost depth which rarely exceeds $50 \mathrm{~cm}$ when the ice-foot is established in late December. The duration of the ice-foot season is therefore an important factor. In addition, we see that with warmer winters in recent decades, there can be several ice-foot cycles in the same winter, that is to say formation of an ice-foot, dismantling, then reformation, so that the absence of an ice-foot in a short period in February can also promote thermoabrasion, as was observed in the winter of 2010 (Figure 17). In this sense, the use of surveillance cameras is essential to properly capture moments without an ice-foot.

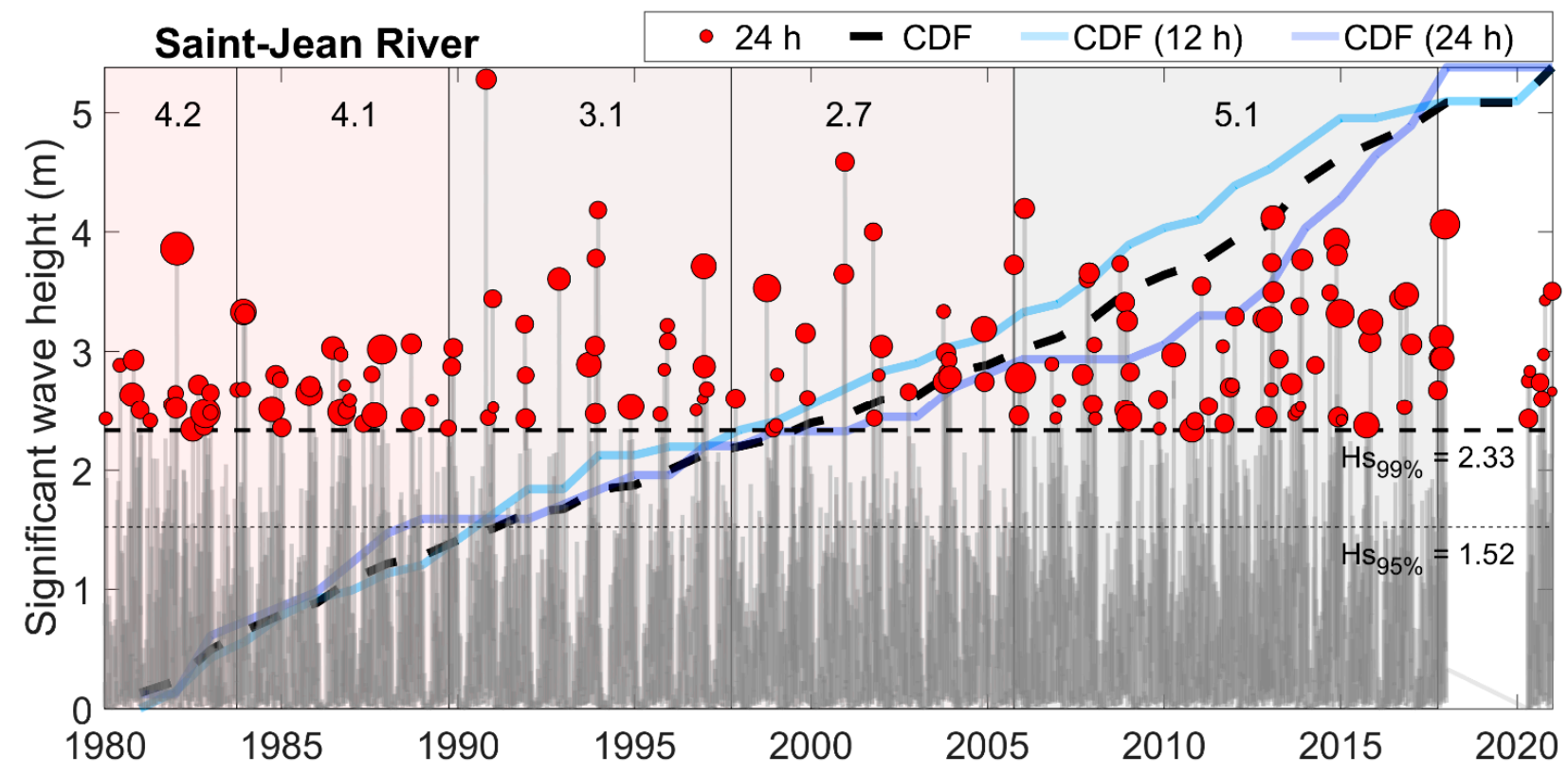

Figure 22. Storm detection over 1980-2020. Each red circle represents a storm, the size of which is a function of the storm duration. Transparent gray line is the significant wave height time series; 99th and 95th percentile thresholds are displayed. The cumulative distribution functions (CDF) of storm events are shown for all storms (dashed black line), storm durations between 12 and $24 \mathrm{~h}$ (clear blue dashed line) and above $24 \mathrm{~h}$ (deep blue dashed line). The different time intervals (1980-1983; 1983-1989; 1989-1997; 1997-2005; 2005-2017) are highlighted with vertical black lines and the number of events per year is indicated for each interval. 

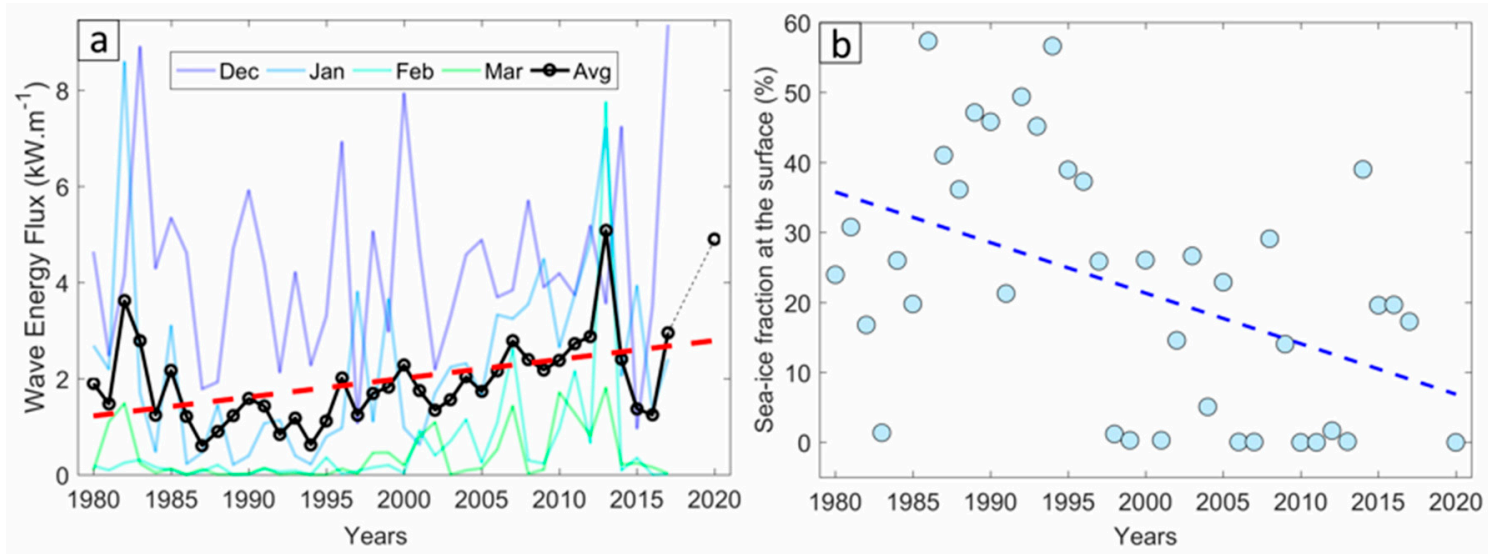

Figure 23. (a) Evolution of the winter-averaged wave energy flux for the 1980-2020 period. The colored lines show the evolution according to the month and the black line the average for the whole winter. The trend of the wave energy flux is highlighted by the linear regression in red (dashed line). (b) Evolution of the ice coverage at the sea-surface during the winter over the 1980-2020 period. The trend of the sea-ice fraction is highlighted by the linear regression in blue (dashed line).

\section{Influence of Temperatures}

Air temperature is often used to characterize the influence of cryogenic processes on cliff erosion, especially with degree hours thawing (freezing) or degree days thawing (freezing). Baranskaya et al. [48] show that $85 \%$ of the temporal variability of cliff erosion in the Gulf of Kruzenstern in the Kara Sea is explained by temperature variations and particularly by air thawing index which generates thermodenudation. In their review of Russian coastal erosion, Ogorodov et al. [25] indicate that the increase in air thawing index and ice-free period duration coincides with an increase in erosion rates. These latter authors also report the results of Grigoriev et al. [113] who also indicate higher erosion rates during the warm periods of the 1930s-1950s and mid-1970s compared to the cooling periods of the 1980s and 1990s. The analysis of hourly temperature data for months when cryogenic processes are active in our study area (December to April), indicates a slight increase in temperatures. It leads to a slight increase in the total of thawing degree hours and a slight decrease in total of freezing degree hours (Figure 24). The temperature also follows intra-decadal cycles that do not make it possible to establish a link with long-term retreat rates. Indeed, the dates of the aerial photographs and the periods of calculation of the erosion rates do not fit perfectly with the cycles of meteorological forcing, which can make it difficult to establish relationships [112].

\subsubsection{Conjuncture of Meteorological-Marine Conditions vs. High Temporal Resolution Monitoring}

With a mean retreat value of $7.5 \mathrm{~m}, 2016-2017$ was the year with by far the highest average retreat measured between 2000 and 2020 (Figure 6). This high value is associated with the storm of 30 December 2016, which caused significant impacts on the coast, inducing the destruction of houses on the North Shore of the Gulf of St. Lawrence [114]. This event makes it possible to explore the importance of the conjuncture of meteorological-marine variables in the rate of retreat of the cliffs. This storm was characterized by relatively high waves, but mostly by water levels which reached the highest values recorded since the beginning of tide gauge records in 1983 (Figure 25). The storm surge reached $1.0 \mathrm{~m}$, driven by winds of $36 \mathrm{~km} / \mathrm{h}$ and low atmospheric pressure of $97.37 \mathrm{kPa}$. We can also see that the height of the waves was higher the day after the storm when the tide was low, which had no impact on the coast (Figure 25). Another important factor that contributed to the cliff's retreat is that the days before the storm were characterized by very cold temperatures that reached $-27^{\circ} \mathrm{C}$, allowing for a deep sediment freeze, which was followed by positive temperatures on December 30 and an absence of an ice-foot. These conditions were conducive to thermoabrasion during the storm of December 30, 2016. The predisposition 
of the cliff by meteorological-marine forcing as well as the conjuncture of environmental variables during the event are all factors that may explain the high retreat values, but taken separately could not explain erosion of this magnitude. Cunliffe et al. [34] also explained rapid cliff retreat by thermoabrasion (7.4 \pm 5.6 and $4.1 \pm 1.1$ respectively for 17 and 4 days) caused by the conjuncture of strong winds, high water levels, wave attack and warm surface temperatures along the Beaufort Sea.

(a)

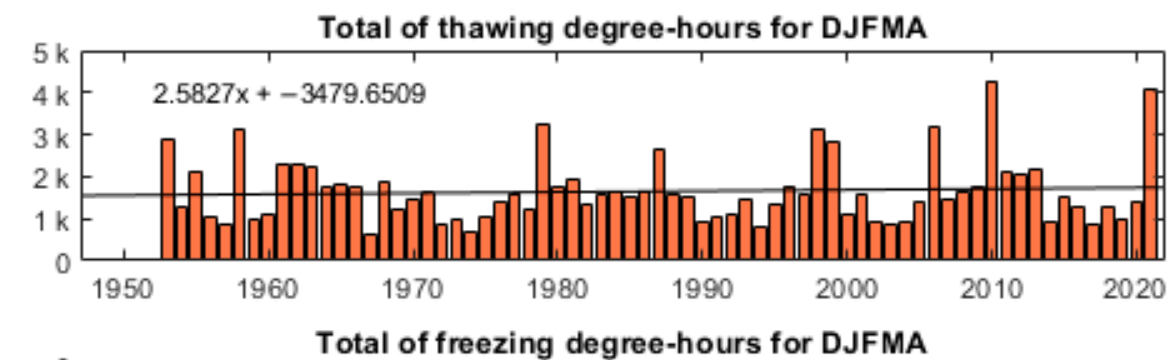

(b)

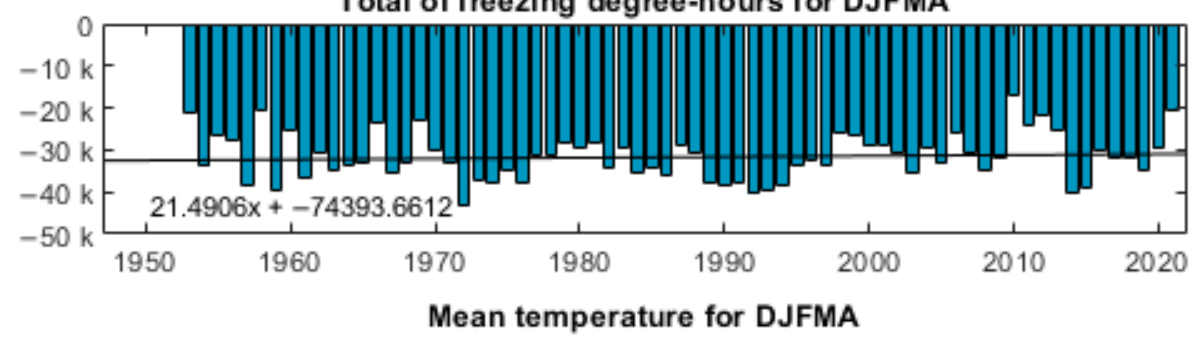

(c)

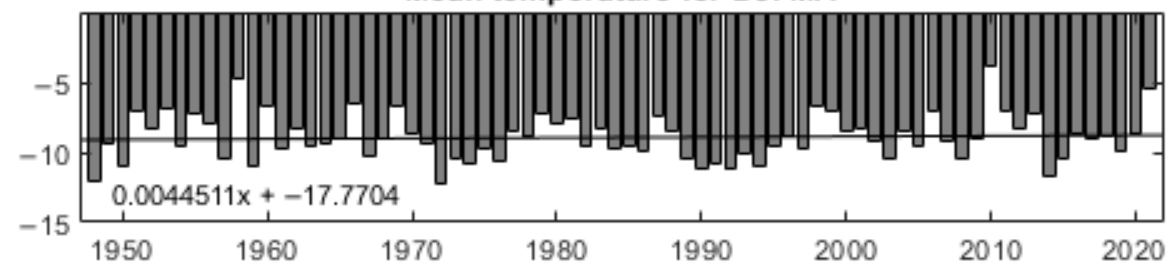

Figure 24. Air temperature inter-annual variation for December, January, February, March, and April (DJFMA). (a) Total of thawing degree hours for DJFMA; (b) total of freezing degree hours for DJFMA; (c) mean temperature for DJFMA.

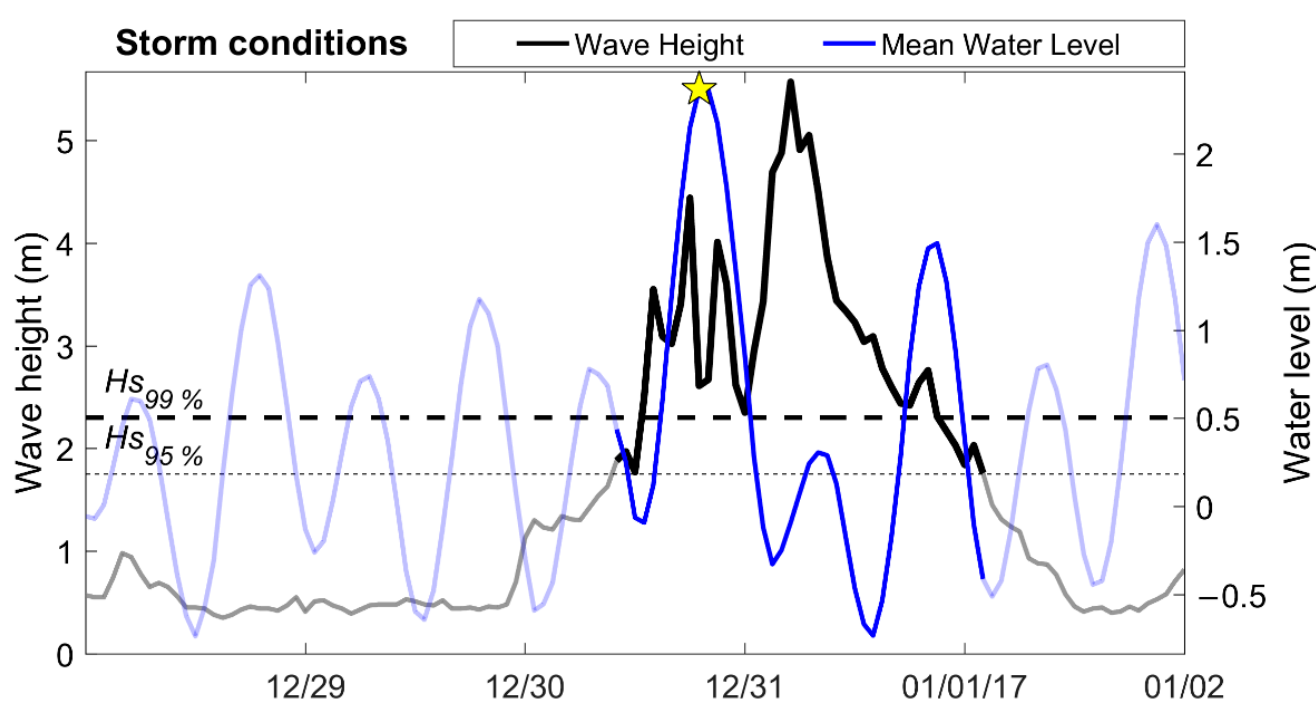

Figure 25. In situ hydrodynamic conditions observed during the 30 December 2016 at the AWAC mooring. The significant wave height time series is displayed in gray (black during the storm), the water level fluctuation is in blue. The highest water level during the storm is highlighted by a yellow star. The 99th and 95th percentiles of significant wave height are shown (dashed lines). 
In the Arctic, where the duration of open water conditions has almost doubled everywhere since 1979 and the air thawing index has increased sharply [25,48], the retreat speeds measured over recent decades are very variable [41] indicating different geomorphological responses. The relationships between hydrodynamic forcing and retreat rates are difficult to establish due in particular to the variability of the geomorphology and lithology of the coast, the ice content of the sediments, trends in relative sea level and sediment inputs [12]. Another explanatory factor that has been identified to explain the lack of a convincing relationship between climatic variables and coast retreat speed is the lack of high temporal resolution data on coast displacement speeds that are averaged and reported in $\mathrm{m}$ per year. However, Jones et al. [30], from high-resolution satellite imagery measured the cliff retreat annually between 2007 and 2016 in the Drew Point area in Alaska. They thus relate the retreat values to open water duration, storm number, storm power, thawing degree day sums, near surface permafrost temperature, and sea surface temperature. However, despite an annual temporal resolution, each of the relationships was judged to be weak and insignificant in explaining the rates of retreat. Analysis of data measured annually for 20 years in our study region comes to the same conclusion. For example, the winter of 2010 was the warmest and among the lowest values of ice concentration, with the average retreat of $2.5 \mathrm{~m}$, lower than the average between 2000 and 2020 (Figures 23 and 24). The period of 2010-2013 presents consecutive years with high values of thawing degree hours with also very low values of ice cover and high values of wave energy flux while the average rate was $2.4 \mathrm{~m}$ per year, including the year with the lowest retreat value of $1.1 \mathrm{~m}$ (2011-2012). Finally, winter 2013 has the highest average of wave power flux (Figure 23), while the retreat value of $1.8 \mathrm{~m}$ was the second lowest in the period from 2000 to 2020 (Figure 6). The interannual variability in the mean retreat values is therefore greater than the variability of the meteorological-marine forcing. This also means that increasing the temporal resolution when calculating retreat rates on a historical scale would probably not be able to significantly improve the relationships between meteorological-marine variables and retreat rates.

We have nevertheless shown that erosion processes and erosion events are linked to different meteorological-marine variables. While it is true that there are more and more data on the rate of retreat of cold coastal regions, erosion processes involved in the retreat of the cliffs are rarely quantified in the literature [104]. However, as we have shown, there are several geomorphological processes that can affect the same segment of the cliff. Very few studies have so far attempted to quantify the relative contribution of different processes to cliff retreat $[19,91]$, particularly in cold coastal regions [35,38,46]. The temporal variability in which the processes take place in daily, seasonal, or annual cycles, sometimes affecting the top, the toe or the face of the cliff, or even the succession of processes that lead to the retreat or to the temporal stabilization of the cliff, or else processes that take place simultaneously, make it difficult to determine the contribution of each process in the shortand long-term retreat of a cliff [46]. It is therefore not surprising to see that in the absence of a real quantification of geomorphological processes, attempts at long-term relationships between the rate of retreat and climatic variables are often inconclusive.

\section{Conclusions}

A combined approach integrating data from hourly to decennial scales allowed the identification of 298 erosion events on a multilayered soft cliff composed of raised deltaic sediments between 2008 and 2012. This number should be considered as a minimum since only a small part of the coastline was covered by each camera, implying that a far greater number of events occurred simultaneously and independently of our observations. Nonetheless, this method allowed us to address the link between all geomorphological processes occurring and the climatic/hydrodynamic conditions throughout the year with a temporal resolution (hourly) rarely reached in other studies. It also highlighted the important role played by environmental variables such as snow cover on the cliff and the presence of an ice-foot, both limiting factors for cryogenic processes. The snow cover 
acts as an insulator and reduces the temperature variation on the cliff face, critical for freeze-thaw cycles and warm spells. The ice-foot protects the cliff base from wave impact and therefore thermoabrasion. On an annual basis, cryogenic processes represent $68 \%$ of the erosion events observed and therefore contribute significantly to the retreat of fine sediment cliffs in cold temperate climates, while the waves and the ice-foot ensure the rapid evacuation of the sediments eroded. We also demonstrate that in the absence of quantitative data on erosion processes, it is difficult to relate climatic and marine forcing and cliff retreat rates even at annual time resolution. The reduction in ice cover is, however, a determining factor in the increase in cliff retreat rates observed since the late 1990s, which results in an increase in wave power and promotes thermoabrasion. This process can therefore be important in cold temperate regions with frost and seasonal ice cover. Further studies on cryogenic-affected coasts should focus on integrating these hydro-climatic and environmental variables in modeling cliff behavior in addition to taking into account all the realized geomorphological processes, regardless of their magnitude, since their repetition combined with their interaction can induce a rapid retreat of the coastline and maintain a mean rate faster than $3 \mathrm{~m}$ per year for several years, as observed in Rivière Saint-Jean.

Author Contributions: P.B. designed the study. P.B. and G.B.-B. wrote the first draft of the manuscript and P.B. the final draft. G.B.-B. performed the analysis of pictures from camera and the digitalization of the aerial images and carried out the historical analysis of the coastal erosion. P.B. performed the annual erosion analysis. G.B.-B. and M.C. performed the analysis of climatic variables and C.C. did the analysis of hydrodynamic variables and storms. All the author contributed to the realization of the figures. P.B. and G.B.-B. contributed to interpreting the results. R.L.B. contributed to write up. All authors have read and agreed to the published version of the manuscript.

Funding: This research was funded by Quebec government and the Ministère de la Sécurité publique du Québec as part of its program for natural risk prevention 2013-2020 and by the Natural Sciences and Engineering Research Council of Canada, P.B. Grant RGPIN-2018-06883.

Institutional Review Board Statement: Not applicable.

Informed Consent Statement: Not applicable.

Data Availability Statement: Not applicable.

Acknowledgments: Thanks to Steeve Dugas for his support for geomatics, mapping and logistics for the field campaigns. Thanks to Patrice Lapointe and the students of the geography Department for the annual surveys for coastal erosion as well as Marie-Andrée Roy, geomatics technician for her contribution to the development of the erosion database. Thanks to Yvon Jolivet for his support in collecting climate data. Finally, thanks for the two reviewers and editor for their comments.

Conflicts of Interest: The authors declare no conflict of interest.

\section{References}

1. Bezerra, M.M.; Moura, D.; Ferreira, O.; Taborda, R. Influence of Wave Action and Lithology on Sea Cliff Mass Movements in Central Algarve Coast, Portugal. J. Coast. Res. 2011, 27, 162-171. [CrossRef]

2. Hackney, C.; Darby, S.E.; Leyland, J. Modelling the response of soft cliffs to climate change: A statistical, process-response model using accumulated excess energy. Geomorphology 2013, 187, 108-121. [CrossRef]

3. Young, A.P.; Guza, R.T.; Flick, R.E.; O’Reilly, W.C.; Gutierrez, R. Rain, waves, and short-term evolution of composite seacliffs in southern California. Mar. Geol. 2009, 267, 1-7. [CrossRef]

4. Pierre, G.; Lahousse, P. The role of groundwater in cliff instability: An example at Cape Blanc-Nez (Pas-de-Calais, France). Earth Surf. Process. Landf. 2006, 31, 31-45. [CrossRef]

5. Lantuit, H.; Overduin, P.P.; Wetterich, S. Recent progress regarding permafrost coasts. Permafr. Periglac. Process. 2013, 24, 120-130. [CrossRef]

6. Emery, K.O.; Kuhn, G.G. Sea cliffs: Their processes, profiles, and classification. Geol. Soc. Am. Bull. 1982, 93, 644-654. [CrossRef]

7. Bernatchez, P.; Dubois, J.-M.M. Bilan des connaissances de la dynamique de l'érosion des côtes du Québec maritime laurentien. Geogr. Phys. Quat. 2004, 58, 45-71. [CrossRef]

8. Hapke, C.J.; Reid, D.; Richmond, B. Rates and trends of coastal change in california and the regional behavior of the beach and cliff system. J. Coast. Res. 2009, 25, 603-615. [CrossRef] 
9. Costa, S.; Maquaire, O.; Letortu, P.; Thirard, G.; Compain, V.; Roulland, T.; Medjkane, M.; Davidson, R.; Graff, K.; Lissak, C.; et al. Sedimentary Coastal Cliffs of Normandy: Modalities and Quantification of Retreat. J. Coast. Res. 2019, 88, 46-60. [CrossRef]

10. Kline, S.W.; Adams, P.N.; Limber, P.W. The unsteady nature of sea cliff retreat due to mechanical abrasion, failure and comminution feedbacks. Geomorphology 2014, 219, 53-67. [CrossRef]

11. Walkden, M.J.A.; Hall, J.W. A predictive Mesoscale model of the erosion and profile development of soft rock shores. Coast. Eng. 2005, 52, 535-563. [CrossRef]

12. Barnhart, K.R.; Anderson, R.S.; Overeem, I.; Wobus, C.; Clow, G.D.; Urban, F.E. Modeling erosion of ice-rich permafrost bluffs along the Alaskan Beaufort Sea coast. J. Geophys. Res. Earth Surf. 2014, 119, 1155-1179. [CrossRef]

13. Sinitsyn, A.O.; Guegan, E.; Shabanova, N.; Kokin, O.; Ogorodov, S. Fifty four years of coastal erosion and hydrometeorological parameters in the Varandey region, Barents Sea. Coast. Eng. 2020, 157, 103610. [CrossRef]

14. Belova, N.G.; Novikova, A.V.; Günther, F.; Shabanova, N.N. Spatiotemporal variability of coastal retreat rates at western Yamal Peninsula, Russia, based on remotely sensed data. J. Coast. Res. 2020, 95, 367-371. [CrossRef]

15. Castedo, R.; Murphy, W.; Lawrence, J.; Paredes, C. A new process-response coastal recession model of soft rock cliffs. Geomorphology 2012, 177-178, 128-143. [CrossRef]

16. Walkden, M.J.; Hall, J.W. A Mesoscale Predictive Model of the Evolution and Management of a Soft-Rock Coast. J. Coast. Res. 2011, 27, 529-543. [CrossRef]

17. Lantuit, H.; Atkinson, D.; Paul Overduin, P.; Grigoriev, M.; Rachold, V.; Grosse, G.; Hubberten, H.-W. Coastal erosion dynamics on the permafrost-dominated Bykovsky Peninsula, north Siberia, 1951-2006. Polar Res. 2011, 30, 7341. [CrossRef]

18. Moses, C.; Robinson, D. Chalk coast dynamics: Implications for understanding rock coast evolution. Earth Sci. Rev. 2011, 109, 63-73. [CrossRef]

19. Young, A.P.; Guza, R.T.; Matsumoto, H.; Merrifield, M.A.; O’Reilly, W.C.; Swirad, Z.M. Three years of weekly observations of coastal cliff erosion by waves and rainfall. Geomorphology 2021, 375, 107545. [CrossRef]

20. Manson, G.K.; Solomon, S.M. Past and future forcing of Beaufort Sea coastal change. Atmos. Ocean 2007, 45, 107-122. [CrossRef]

21. Lantuit, H.; Pollard, W.H. Fifty years of coastal erosion and retrogressive thaw slump activity on Herschel Island, southern Beaufort Sea, Yukon Territory, Canada. Geomorphology 2008, 95, 84-102. [CrossRef]

22. Ramage, J.L.; Irrgang, A.M.; Herzschuh, U.; Morgenstern, A.; Couture, N.; Lantuit, H. Terrain controls on the occurrence of coastal retrogressive thaw slumps along the Yukon Coast, Canada. J. Geophys. Res. Earth Surf. 2017, 122, 1619-1634. [CrossRef]

23. Berry, H.B.; Whalen, D.; Lim, M. Long-term ice-rich permafrost coast sensitivity to air temperatures and storm influence: Lessons from Pullen Island, Northwest Territories, Canada. Arct. Sci. 2021, 7, 723-745. [CrossRef]

24. Barnhart, K.R.; Overeem, I.; Anderson, R.S. The effect of changing sea ice on the physical vulnerability of Arctic coasts. Cryosphere 2014, 8, 1777-1799. [CrossRef]

25. Ogorodov, S.; Aleksyutina, D.; Baranskaya, A.; Shabanova, N.; Shilova, O. Coastal erosion of the Russian Arctic: An overview. J. Coast. Res. 2020, 95, 599-604. [CrossRef]

26. Hoque, M.A.; Pollard, W.H. Arctic coastal retreat through block failure. Can. Geotech. J. 2009, 46, 1103-1115. [CrossRef]

27. Günther, F.; Overduin, P.P.; Yakshina, I.A.; Opel, T.; Baranskaya, A.V.; Grigoriev, M.N. Observing Muostakh disappear: Permafrost thaw subsidence and erosion of a ground-ice-rich island in response to arctic summer warming and sea ice reduction. Cryosphere 2015, 9, 151-178. [CrossRef]

28. Günther, F.; Overduin, P.P.; Sandakov, A.V.; Grosse, G.; Grigoriev, M.N. Short- and long-term thermo-erosion of ice-rich permafrost coasts in the Laptev Sea region. Biogeosciences 2013, 10, 4297-4318. [CrossRef]

29. Jones, B.M.; Arp, C.D.; Jorgenson, M.T.; Hinkel, K.M.; Schmutz, J.A. Increase in the rate and uniformity of coastline erosion in Arctic Alaska. Geophys. Res. Lett. 2009, 36. [CrossRef]

30. Jones, B.M.; Farquharson, L.M.; Baughman, C.A.; Buzard, R.M.; Arp, C.D.; Grosse, G.; Bull, D.L.; Gunther, F.; Nitze, I.; Urban, F.; et al. A decade of remotely sensed observations highlight complex processes linked to coastal permafrost bluff erosion in the Arctic. Environ. Res. Lett. 2018, 13, 115001. [CrossRef]

31. Overeem, I.; Anderson, R.S.; Wobus, C.W.; Clow, G.D.; Urban, F.E.; Matell, N. Sea ice loss enhances wave action at the Arctic coast. Geophys. Res. Lett. 2011, 38. [CrossRef]

32. Aleksyutina, D.; Novikova, A.; Baranskaya, A.; Shilova, O.; Ogorodov, S. Using multi-temporal aerial and space imagery for coastal dynamics investigations at Kara and Pechora Seas, Russian Arctic. In Proceedings of the 18th International Multidisciplinary Scientific GeoConference (SGEM 2018), Albena, Bulgaria, 2-8 July 2018; Volume 18, pp. 265-272. [CrossRef]

33. Irrgang, A.M.; Lantuit, H.; Manson, G.K.; Günther, F.; Grosse, G.; Overduin, P.P. Variability in rates of coastal change along the Yukon coast, 1951 to 2015. J. Geophys. Res. Earth Surf. 2018, 123, 779-800. [CrossRef]

34. Cunliffe, A.M.; Tanski, G.; Radosavljevic, B.; Palmer, W.F.; Sachs, T.; Lantuit, H.; Kirby, J.T.; Myers-Smith, I.H. Rapid retreat of permafrost coastline observed with aerial drone photogrammetry. Cryosphere 2019, 13, 1513-1528. [CrossRef]

35. Roland, C.J.; Zoet, L.K.; Rawling III, J.E.; Cardiff, M. Seasonality in cold coast bluff erosion processes. Geomorphology 2021, 374, 107520. [CrossRef]

36. Bernatchez, P.; Dubois, J.-M.M. Seasonal Quantification of Coastal Processes and Cliff Erosion on Fine Sediment Shorelines in a Cold Temperate Climate, North Shore of the St. Lawrence Maritime Estuary, Québec. J. Coast. Res. 2008, 24, 169-180. [CrossRef]

37. Obu, J.; Lantuit, H.; Grosse, G.; Günther, F.; Sachs, T.; Helm, V.; Fritz, M. Coastal erosion and mass wasting along the Canadian Beaufort Sea based on annual airborne LiDAR elevation data. Geomorphology 2017, 293, 331-346. [CrossRef] 
38. Gibbs, A.E.; Nolan, M.; Richmond, B.M.; Snyder, A.G.; Erikson, L.H. Assessing patterns of annual change to permafrost bluffs along the North Slope coast of Alaska using high-resolution imagery and elevation models. Geomorphology 2019, 336, 152-164. [CrossRef]

39. Lim, M.; Whalen, D.; Mann, P.; Fraser, P.; Berry, H.B.; Irish, C.; Cockney, K.; Woodward, J. Effective monitoring of permafrost coast erosion: Wide-scale storm impacts on outer islands in the Mackenzie Delta area. Front. Earth Sci. 2020, 8. [CrossRef]

40. Joyal, G.; Lajeunesse, P.; Morissette, A.; Bernatchez, P. Influence of lithostratigraphy on the retreat of an unconsolidated sedimentary coastal cliff (St. Lawrence estuary, eastern Canada). Earth Surf. Process. Landf. 2016, 41, 1055-1072. [CrossRef]

41. Lantuit, H.; Overduin, P.P.; Couture, N.; Wetterich, S.; Aré, F.; Atkinson, D.; Brown, J.; Cherkashov, G.; Drozdov, D.; Forbes, D.L.; et al. The Arctic coastal dynamics database: A new classification scheme and statistics on Arctic permafrost coastlines. Estuaries Coasts 2012, 35, 383-400. [CrossRef]

42. Hoque, M.A.; Pollard, W.H. Stability of permafrost dominated coastal cliffs in the Arctic. Polar Sci. 2016, 10, 79-88. [CrossRef]

43. Quinn, J.D.; Rosser, N.J.; Murphy, W.; Lawrence, J.A. Identifying the behavioural characteristics of clay cliffs using intensive monitoring and geotechnical numerical modelling. Geomorphology 2010, 120, 107-122. [CrossRef]

44. Vasiliev, A.; Kanevskiy, M.; Cherkashov, G.; Vanshtein, B. Coastal dynamics at the Barents and Kara Sea key sites. Geo-Mar. Lett. 2005, 25, 110-120. [CrossRef]

45. Zwissler, B.; Oommen, T.; Vitton, S. A study of the impacts of freeze-thaw on cliff recession at the Calvert Cliffs in Calvert County, Maryland. Geotech. Geol. Eng. 2014, 32, 1133-1148. [CrossRef]

46. Kaczmarek, H.; Tyszkowski, S.; Bartczak, A.; Kramkowski, M.; Wasak, K. The role of freeze-thaw action in dam reservoir cliff degradation assessed by terrestrial laser scanning: A case study of Jeziorsko Reservoir (central Poland). Sci. Total Environ. 2019, 690, 1140-1150. [CrossRef]

47. Bogatova, D.; Buldovich, S.; Khilimonyuk, V. Snow Patches and Their Influence on Coastal Erosion at Baydaratskaya Bay Coast, Kara Sea, Russian Arctic. Water 2021, 13, 1432. [CrossRef]

48. Baranskaya, A.; Novikova, A.; Shabanova, N.; Belova, N.; Maznev, S.; Ogorodov, S.; Jones, B.M. The role of thermal denudation in erosion of ice-rich permafrost coasts in an enclosed bay (Gulf of Kruzenstern, western Yamal, Russia). Front. Earth Sci. 2021, 8, 659. [CrossRef]

49. Korte, S.; Gieschen, R.; Stolle, J.; Goseberg, N. Physical Modelling of Arctic Coastlines-Progress and Limitations. Water 2020, 12, 2254. [CrossRef]

50. Kobayashi, N.; Vidrine, J.C.; Nairn, R.B.; Soloman, S.M. Erosion of frozen cliffs due to storm surge on Beaufort Sea Coast. J. Coast. Res. 1999, 15, 332-344.

51. Islam, M.A.; Lubbad, R.; Afzal, M.S. A Probabilistic Model of Coastal Bluff-Top Erosion in High Latitudes Due to Thermoabrasion: A Case Study from Baydaratskaya Bay in the Kara Sea. J. Mar. Sci. Eng. 2020, 8, 169. [CrossRef]

52. Boucher-Brossard, G.; Bernatchez, P.; Corriveau, M.; Jolivet, Y. Calculating lateral frost front penetration in a rapidly retreating cliff of fine sediments. Permafr. Periglac. Process. 2017, 28, 32-41. [CrossRef]

53. Boucher-Brossard, G. Rythme et Modes de Recul des Falaises à Sommet Tourbeux de la Côte-Nord de l'estuaire Maritime et du Golfe du Saint-Laurent. Master's Thesis, Université du Québec à Rimouski, Rimouski, QC, Canada, 2012.

54. Dubois, J.-M.M. Environnements Quaternaires et Évolution Post-Glaciaire d'une Zone Côtière en Émersion en Bordure Sud du Bouclier Canadien: La Moyenne Côte-Nord du Saint-Laurent, Québec. Ph.D. Thesis, University of Ottawa, Ottawa, ON, Canada, 1979.

55. Dubois, J.-M.M.; Martel, Y.A.; Côté, D.; Nadeau, L. Les ortsteins du Québec: Répartition géographique, relations géomorphologiques et essai de datation. Géographe Can. 1990, 34, 303-317. [CrossRef]

56. Dubois, J.-M.M.; et St-Pierre, L. Cartes des Matériaux D'emprunt et des Zones de Risques sur la Moyenne-Côte-Nord du Saint-Laurent; Université de Sherbrooke: Sherbrooke, QC, Canada, 1986.

57. Ross, N.; Long, B. Évolution morphosédimentaire de la barre de déferlement: Un exemple dans le golfe du Saint-Laurent, Québec. Geogr. Phys. Quat. 1989, 43, 377-388. [CrossRef]

58. Fisheries and Oceans Canada Tides, Currents and Water Levels. Available online: http://www.niveauxdeau.gc.ca/fra/accueil (accessed on 14 November 2021).

59. Han, G.; Ma, Z.; Chen, N.; Thomson, R.; Slangen, A. Changes in mean relative sea level around Canada in the twentieth and twenty-first centuries. Atmos. Ocean 2015, 53, 452-463. [CrossRef]

60. Peel, M.C.; Finlayson, B.L.; McMahon, T.A. Updated world map of the Köppen-Geiger climate classification. Hydrol. Earth Syst. Sci. 2007, 11, 1633-1644. [CrossRef]

61. Environment Canada Climate. Available online: http:/ / www.climat.meteo.gc.ca/index_f.html (accessed on 12 May 2013).

62. Thieler, E.R.; Martin, D.; Ergul, A. Digital Shoreline Analysis System (DSAS) version 2.0: An ArcView Extension for Calculating Shoreline Change; USGS Open-File Report 2003-76; U.S. Geological Survey: Reston, VA, USA, 2003.

63. Fletcher, C.; Rooney, J.; Limt, M.B.S.; Richmond, B. Mapping Shoreline Change Using Digital Orthophotogrammetry on Maui, Hawaii. J. Coast. Res. 2003, 38, 106-124.

64. Gorokhovich, Y.; Leiserowiz, A. Historical and Future Coastal Changes in Northwest Alaska. J. Coast. Res. 2012, 28, 174-186. [CrossRef]

65. Morton, R.A.; Miller, T.L. National Assessment Of Shoreline Change: Part 2, Historical Shoreline Changes and Associated Coastal Land Loss along The U.S. Southeast Atlantic Coast; Open-File Report 2005-1401; US Geological Survey: Reston, VA, USA, 2005. [CrossRef] 
66. Mckee, T.B.; Doesken, N.J.; Kleist, J. The relationship of drought frequency and duration to time scales. In Proceedings of the Eight Conference on Applied Climatology, Anaheim, CA, USA, 17-22 January 1993; pp. 179-184.

67. Berggren, W.P. Prediction of temperature distribution in frozen soils. Eos Trans. AGU 1943, 24, 71-77. [CrossRef]

68. Aldrich, H.P.; Paynter, H.M. Analytical Studies of Freezing and Thawing of Soils; Technical Report No. 42; Arctic Construction and Frost Effects Laboratory: Boston, MA, USA, 1953.

69. Tolman, H.L.; WAVEWATCH III Development Group. User Manual and System Documentation of WAVEWATCH III Version 4.18; Technical Note; Environmental Modeling Center, National Centers for Environmental Prediction, National Weather Service, National Oceanic and Atmospheric Administration, U.S. Department of Commerce: College Park, MD, USA, 2014.

70. Bernatchez, P.; Lambert, A.; Bismuth, E.; Didier, D.; Senneville, S.; Dumont, D.; Caveen, J.; Sévigny, C.; Beaudry, J.; Bandet, M. Programme de Mesure et de Modélisation de la Morphodynamique de l'Erosion et de la Submersion Côtière dans l'Estuaire et Le Golfe du Saint-Laurent (MoDESCo), Phase II: Rapport Final; Rapport Remis au Ministère de la Sécurité Publique du Québec; Chaire de Recherche en Géoscience Côtière, Laboratoire de Dynamique et de Gestion Intégrée des Zones Côtières, Université du Québec à Rimouski: Rimouski, QC, Canada, 2017; 172p.

71. Bandet, M.; Caulet, C.; Baudry, J.; Didier, D.; Dubuc, D.; Marion, N.; McKinnon, R.; Paul-Hus, C.; Caveen, J.; Sévigny, C.; et al. Programme de Mesure et de Modélisation de la Morphodynamique de l'Érosion et de la Submersion Côtière dans l'Estuaire et le Golfe du SaintLaurent (MoDESCo), Phase III: Rapport Final; Rapport Remis au Ministère de la Sécurité Publique du Québec; Chaire de Recherche en Géoscience Côtière, Laboratoire de Dynamique et de Gestion Intégrée des Zones Côtières, Université du Québec à Rimouski: Rimouski, QC, Canada, 2020; 259p.

72. Masselink, G.; Scott, T.; Poate, T.; Russell, P.; Davidson, M.; Conley, D. The extreme 2013/2014 winter storms: Hydrodynamic forcing and coastal response along the southwest coast of England. Earth Surf. Process. Landf. 2016, 41, 378-391. [CrossRef]

73. Bernatchez, P.; Boucher-Brossard, G.; Corriveau, M.; Jolivet, Y. Impacts des Changements Climatiques sur l'Erosion des Falaises de l'Estuaire Maritime et du Golfe du Saint-Laurent; Rapport de Recherche Remis au Ministère de la Sécurité Publique du Québec et au Consortium Ouranos; Chaire de Recherche en Géoscience Côtière, Laboratoire de Dynamique et de Gestion Intégrée des Zones Côtières, Université du Québec à Rimouski: Rimouski, QC, Canada, 2014; 166p.

74. Bernatchez, P.; Jolivet, Y.; Corriveau, M. Development of an automated method for continuous detection and quantification of cliff erosion events. Earth Surf. Process. Landf. 2011, 36, 347-362. [CrossRef]

75. Matsuoka, N.; Hirakawa, K.; Watanabe, T.; Haeberli, W.; Keller, F. The role of diurnal, annual and millenial freeze-thaw cycles in controlling alpine slope instability. In Proceedings of the Permafrost Seventh International Conference, Yellowknife, NWT, Canada, 23-27 June 1998; Volume 55, pp. 711-717.

76. Andersland, O.B.; Ladanyi, B. Frozen Ground Engineering, 2nd ed.; Wiley: Hoboken, NJ, USA, 2003; ISBN 978-0-471-61549-1.

77. Couper, P. Effects of silt-clay content on the susceptibility of river banks to subaerial erosion. Geomorphology 2003, 56, 95-108. [CrossRef]

78. Harris, C.; Gallop, M.; Coutard, J.-P. Physical modelling of gelifluction and frost creep: Some results of a large-scale laboratory experiment. Earth Surf. Process. Landf. 1993, 18, 383-398. [CrossRef]

79. Gunzburger, Y.; Merrien-Soukatchoff, V. Near-surface temperatures and heat balance of bare outcrops exposed to solar radiation. Earth Surf. Process. Landf. 2011, 36, 1577-1589. [CrossRef]

80. Zhu, L.; Wang, J.; Li, B. The impact of solar radiation upon rock weathering at low temperature: A laboratory study. Permafr. Periglac. Process. 2003, 14, 61-67. [CrossRef]

81. Hall, K. Evidence for freeze-thaw events and their implications for rock weathering in northern Canada. Earth Surf. Process. Landf. 2004, 29, 43-57. [CrossRef]

82. Ødegård, R.S.; Sollid, J.L. Coastal cliff temperatures related to the potential for cryogenic weathering processes, western Spitsbergen, Svalbard. Polar Res. 1993, 12, 95-106. [CrossRef]

83. Matsuoka, N. Diurnal freeze-thaw depth in rockwalls: Field measurements and theoretical considerations. Earth Surf. Process. Landf. 1994, 19, 423-435. [CrossRef]

84. Matsumoto, H.; Yamada, S.; Hirakawa, K. Relationship between ground ice and solifluction: Field measurements in the Daisetsu Mountains, northern Japan. Permafr. Periglac. Process. 2010, 21, 78-89. [CrossRef]

85. Lewkowicz, A.G. Rate of short-term ablation of exposed ground ice, Banks Island, Northwest Territories, Canada. J. Glaciol. 1986, 32, 511-519. [CrossRef]

86. Matsuoka, N.; Sakai, H. Rockfall activity from an alpine cliff during thawing periods. Geomorphology 1999, 28, 309-328. [CrossRef]

87. Harris, C.; Kern-Luetschg, M.; Murton, J.; Font, M.; Davies, M.; Smith, F. Solifluction processes on permafrost and non-permafrost slopes: Results of a large-scale laboratory simulation. Permafr. Periglac. Process. 2008, 19, 359-378. [CrossRef]

88. Wilcock, P.R.; Miller, D.S.; Shea, R.H.; Kerkin, R.T. Frequency of effective wave activity and the recession of coastal bluffs: Calvert Cliffs, Maryland. J. Coast. Res. 1998, 14, 256-268.

89. Thomas, J.T.; Iverson, N.R.; Burkart, M.R. Bank-collapse processes in a valley-bottom gully, western Iowa. Earth Surf. Process. Landf. 2009, 34, 109-122. [CrossRef]

90. Are, F.E. Thermal abrasion of sea coasts. Polar Geogr. Geol. 1988, 12, 157. [CrossRef]

91. Greenwood, R.O.; Orford, J.D. Temporal patterns and processes of retreat of drumlin coastal cliffs-Strangford Lough, Northern Ireland. Geomorphology 2008, 94, 153-169. [CrossRef]

92. Crosta, G.; Di Prisco, C. On slope instability induced by seepage erosion. Can. Geotech. J. 1999, 36, 1056-1073. [CrossRef] 
93. Brooks, S.M.; Spencer, T.; Boreham, S. Deriving mechanisms and thresholds for cliff retreat in soft-rock cliffs under changing climates: Rapidly retreating cliffs of the Suffolk coast, UK. Geomorphology 2012, 153-154, 48-60. [CrossRef]

94. Collins, B.D.; Sitar, N. Processes of coastal bluff erosion in weakly lithified sands, Pacifica, California, USA. Geomorphology 2008, 97, 483-501. [CrossRef]

95. Jaiswal, P.; van Westen, C.J. Estimating temporal probability for landslide initiation along transportation routes based on rainfall thresholds. Geomorphology 2009, 112, 96-105. [CrossRef]

96. Gaskin, S.J.; Pieterse, J.; Shafie, A.A.; Lepage, S. Erosion of undisturbed clay samples from the banks of the St. Lawrence River. Can. J. Civ. Eng. 2003, 30, 585-595. [CrossRef]

97. Dawson, S.A.; Evans, J.E. Geological Causes of Local Variation in Coastal Bluff Recession Rates, Northeast Ohio Shoreline of Lake Erie. Environ. Geosci. 2001, 8, 1-10. [CrossRef]

98. Jones, J.R.; Cameron, B.; Fisher, J.J.; Island, T.; Cameront, B.; Fishert, J.J. Analysis of Cliff Retreat and Shoreline Erosion: Thompson Island, Massachusetts, U.S.A. J. Coast. Res. 1993, 9, 87-96.

99. Manson, G.K. Subannual erosion and retreat of cohesive till bluff's, McNab's Island, Nova Scotia. J. Coast. Res. 2002, 18, 421-432.

100. Carpenter, N.E.; Dickson, M.E.; Walkden, M.J.A.; Nicholls, R.J.; Powrie, W. Effects of varied lithology on soft-cliff recession rates. Mar. Geol. 2014, 354, 40-52. [CrossRef]

101. Greenwood, R.O.; Orford, J.D. Factors controlling the retreat of drumlin coastal cliffs in a low energy marine environmentStrangford Lough, Northern Ireland. J. Coast. Res. 2007, 23, 285-297. [CrossRef]

102. Gubar'Kov, A.A.; Leibman, M.O.; Mel'Nikov, V.P.; Khomutov, A.V. Contribution of lateral thermoerosion and thermal denudation to coastal retreat of the Yugorskii Peninsula. In Doklady Earth Sciences; Springer Nature AG: Switzerland, 2008; Volume 423, p. 1452. Available online: https: / / www.proquest.com/openview /4bb0d8f33567b96e548251c3faf4f893/1?pq-origsite=gscholar\&cbl=54876 (accessed on 15 July 2021). [CrossRef]

103. Oliva, M.; Ortiz, A.G.; Franch, F.S.; Catarineu, M.S. Present-day solifluction processes in the semi-arid range of Sierra Nevada (Spain). Arct. Antarct. Alp. Res. 2014, 46, 365-370. [CrossRef]

104. Quinn, J.D.; Philip, L.K.; Murphy, W. Understanding the recession of the Holderness Coast, east Yorkshire, UK: A new presentation of temporal and spatial patterns. Q. J. Eng. Geol. Hydrogeol. 2009, 42, 165-178. [CrossRef]

105. Lee, E.M.; Meadowcroft, I.C.; Hall, J.W.; Walkden, M.J. Coastal landslide activity: A probabilistic simulation model. Bull. Eng. Geol. Environ. 2002, 61, 347-355. [CrossRef]

106. Are, F.; Reimnitz, E.; Grigoriev, M.; Hubberten, H.W.; Rachold, V. The influence of cryogenic processes on the erosional Arctic shoreface. J. Coast. Res. 2008, 24, 110-121. [CrossRef]

107. Sessford, E.G.; Bæverford, M.G.; Hormes, A. Terrestrial processes affecting unlithified coastal erosion disparities in central fjords of Svalbard. Polar Res. 2015, 34, 24122. [CrossRef]

108. Ping, C.L.; Michaelson, G.J.; Guo, L.; Jorgenson, M.T.; Kanevskiy, M.; Shur, Y.; Dou, F.; Liang, J. Soil carbon and material fluxes across the eroding Alaska Beaufort Sea coastline. J. Geophys. Res. 2011, 116. [CrossRef]

109. Obu, J.; Lantuit, H.; Fritz, M.; Pollard, W.H.; Sachs, T.; Günther, F. Relation between planimetric and volumetric measurements of permafrost coast erosion: A case study from Herschel Island, western Canadian Arctic. Polar Res. 2016, 35, 30313. [CrossRef]

110. Farquharson, L.M.; Mann, D.H.; Swanson, D.K.; Jones, B.M.; Buzard, R.M.; Jordan, J.W. Temporal and spatial variability in coastline response to declining sea-ice in northwest Alaska. Mar. Geol. 2018, 404, 71-83. [CrossRef]

111. Brown, J.; Jorgenson, M.T.; Smith, O.P.; Lee, W. Long-term rates of coastal erosion and carbon input, Elson Lagoon, Barrow, Alaska. In Proceedings of the Eighth International Conference on Permafrost, Zurich, Switzerland, 21-25 July 2003; Volume 21, p. 25, ISBN 9058095827.

112. Belova, N.G.; Shabanova, N.N.; Ogorodov, S.A.; Kamalov, A.M.; Kuznetsov, D.E.; Baranskaya, A.V.; Novikova, A.V. Erosion of permafrost coasts of Kara Sea near Kharasavey Cape, Western Yamal. Earth's Cryosphere 2017, 21, 73-83. [CrossRef]

113. Grigoriev, M.N.; Razumov, S.O.; Kunitzkiy, V.V.; Spektor, V.B. Dynamics of the Russian East Arctic Sea coast: Major factors, regularities and tendencies. Earth's Cryosphere 2006, 10, 74-94.

114. Corriveau, M.; Bernatchez, P.; Dugas, S. Mise à Jour de la Cartographie des Marges de Sécurité en Erosion Côtière pour le Secteur de Gallix, Municipalité de Sept-Îles: Analyse de l'Evolution Côtière et de la Dynamique; Rapport Remis au Ministère de la Sécurité Publique du Québec; Chaire de Recherche en Géoscience Côtière, Laboratoire de Dynamique et de Gestion Intégrée des Zones Côtières, Université du Québec à Rimouski: Rimouski, QC, Canada, 2019; 108p. 